\title{
Identify the components of sustainability reporting in the insurance industry
}

\author{
Mahnaz Mahmoudkhani \\ Ph.D. Candidate, Department of Accounting, Faculty of Social Sciences \& \\ Economics, Alzahra University, Tehran, \\ Iran(m.mahmoudkhani@alzahra.ac.ir) \\ Ali Rahmani* \\ Professor, Department of Accounting, Faculty of Social Sciences \& \\ Economics, Alzahra University(Corresponding Author) \\ rahmani@alzahra.ac.ir \\ Saeid Homayoun \\ 3Senior Lecturer, Department of Accounting, Faculty of Education and \\ Business, University of Gavle, Sweden(homayoun@hig.se)

\section{Leili Niakan} \\ Assistant Professor, Department of Macro Insurance Studies, Insurance \\ Research Center,Tehran,Iran(niakan@irc.ac.ir)
}

\begin{abstract}
:
The reporting approach is not limited to disclose financial events in accounting. Therefore, in response to stakeholder demand and increased accountability to society, many companies around the world publish their information about environmental, social, and governance performance, which are known as sustainability reporting. The purpose of this study is to identify the environmental, social, and governance components in the insurance industry. Qualitative content analysis was used to identify the components of sustainability. Twelve sustainability reports of foreign insurance companies with the highest environmental, social and Governance scores in the Thomson Reuters database were selected by purposive sampling method. Findings showed that the components of sustainability reporting include important general information of company, sustainable investment, sustainable insurance, environmental issues, customers and employees, Diversity, social inclusion and fair opportunities, risk management, education and development, health and Welfare, compliance management, climate change, supply chain, organization integrity, Leadership structure, corporate citizen activity, and information technology. The findings also suggest that insurance companies consider a wide range of stakeholders as the target audience for their sustainability reports. The results of this study can be used by Iranian insurance companies to prepare sustainability reports.
\end{abstract}

Keywords: Sustainability Reporting, Sustainable Development, Content Analysis, Insurance Industry.

Copyrights:

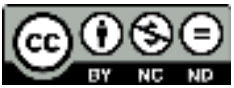

This license only allowing others to download your works and share them with others as long as they credit you, but they can't change them in any way or use them commercial. 


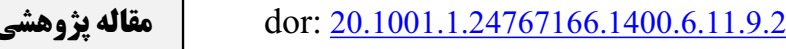

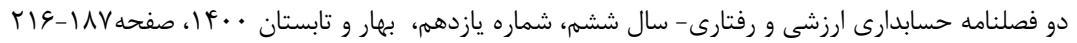

شناسايى مؤلفههاى كزارشكرى بايدارى در صنعت بيمه

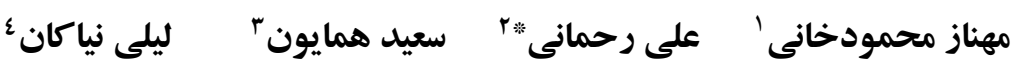

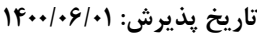

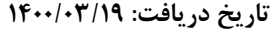

جكيله

امروزه رويكرد كزارشخرى در حسابدارى، صرفا به افشاء رويدادهاى مالى منتهى نمى شود. از داز

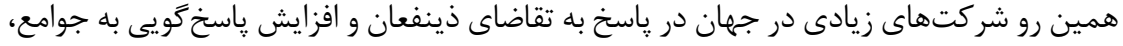

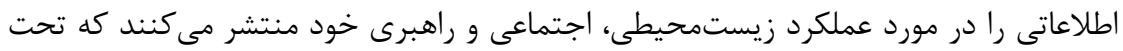

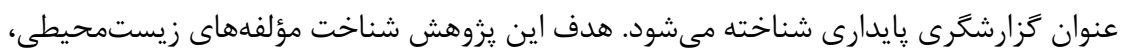

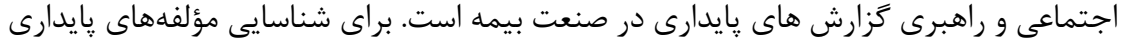

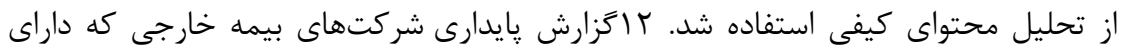

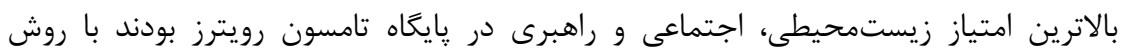

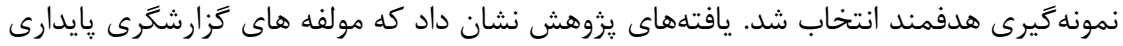
شامل كليات و خلاصههاى مهمى از اطلاعات شركت، سرمايه گذارى پايدارى، بيمه يايدار، اقدامدامدات

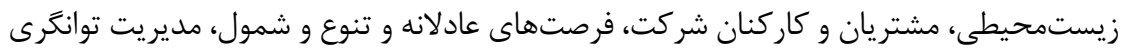
و ريسك ، آموزش و توسعه، سلامت و رفاه، مديريت تطبيق، تغيير اقليم، زنجيره تامين، عوامل

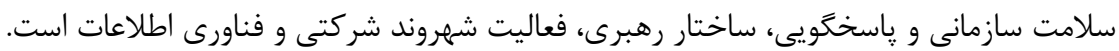

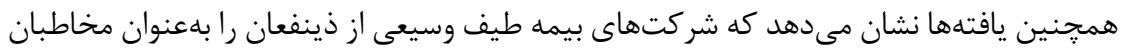

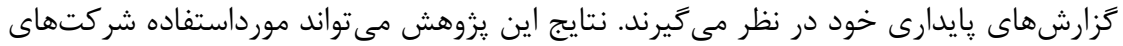
بيمه داخلى در تدوين گزارشهاى بإيدارى قرار گيردا.

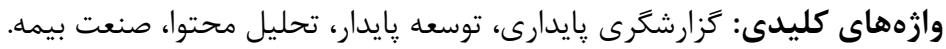

'دانشجوى دكترى، گروه حسابدارى، دانشكده علوم اجتماعى و اقتصاد، دانشكاه الزهرا، تهران، ايران m.mahmoudkhani@alzahra.ac.ir "استاد، كروه حسابدارى، دانشكده علوم اجتماعى و اقتصاد، دانشاه الزهرا، تهران، ايران(نويسنده مسئول)، rahmani@alzahra.ac.ir

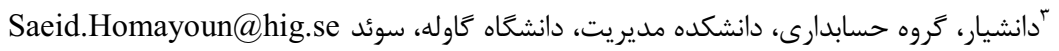

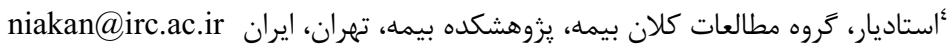


${ }^{1}$ The Global Reporting Initiative (GRI)

${ }^{2}$ The Sustainability Accounting Standards Board (SASB)

${ }^{3}$ Sustainability reporting 
زيستمحيطى، اجتماعى و راهبرى خاص هر صنعت با توجه به ويزگگ هاى خاصى كه هر صنعتى

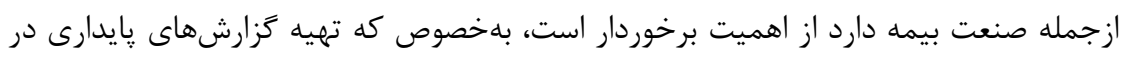

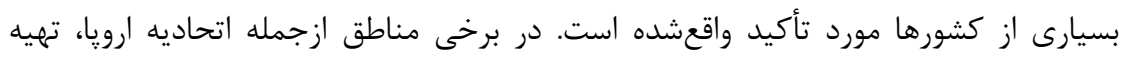

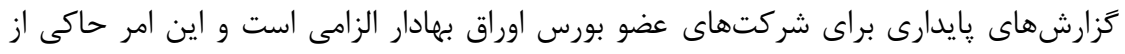

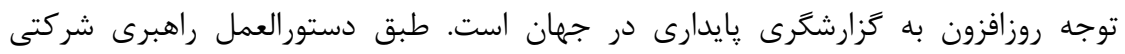

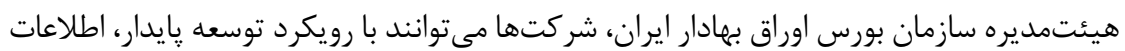
لازم در زمينٔه مسائل مالى، اقتصادى، محيطى و اجتماعى ارائه نمايند.

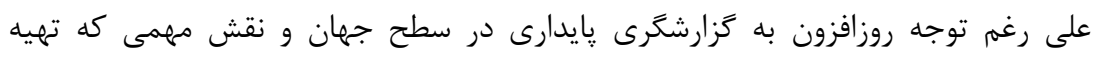

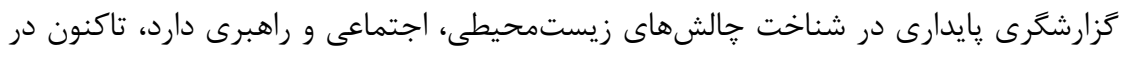

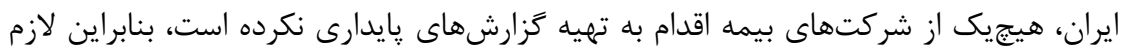

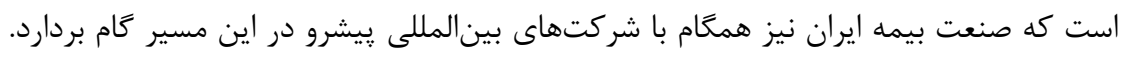

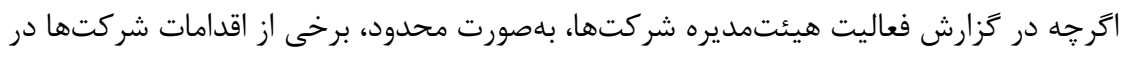

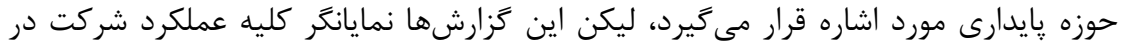

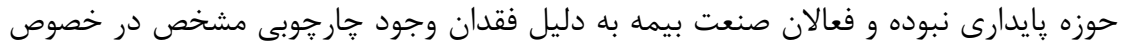

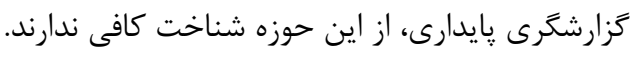

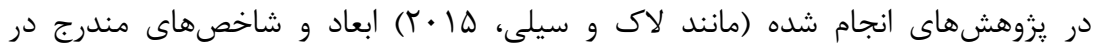

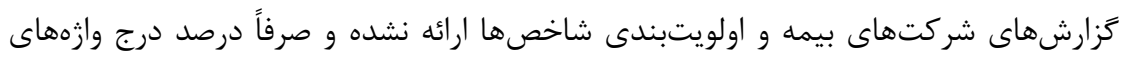

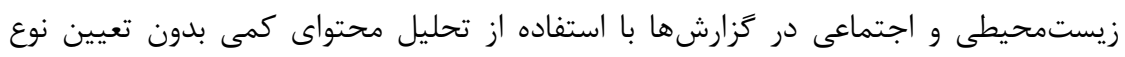

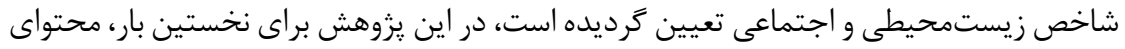

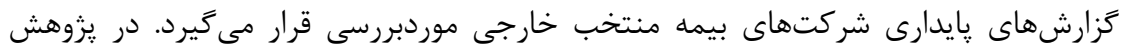

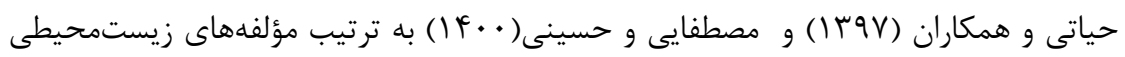

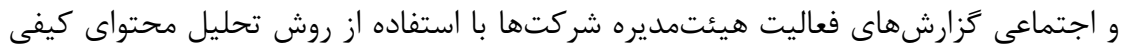

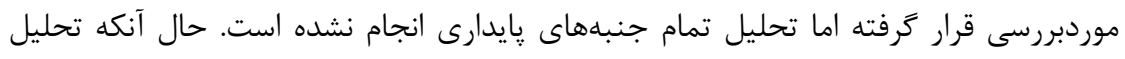

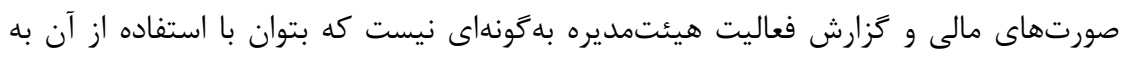

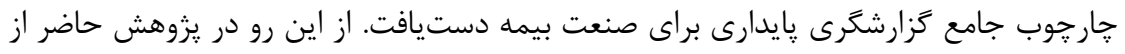

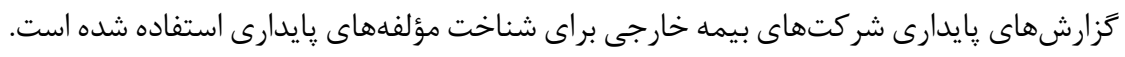




\section{r-مبانى نظرى و يِيشينه يزوهش}

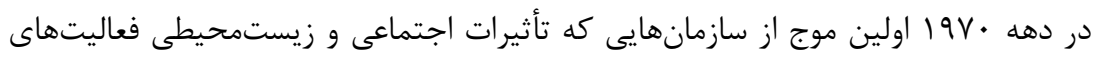

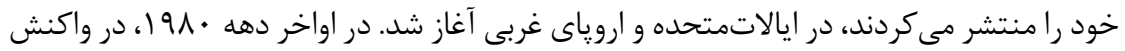

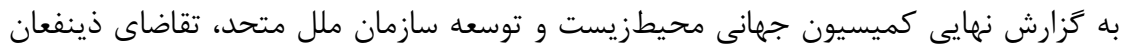
در خصوص تعهدات بيشتر شركتها در قبال توسعه يايدار افزايش يافت. در اوايل دهه • •199،

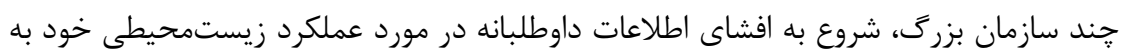

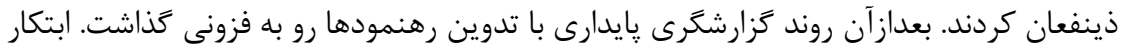

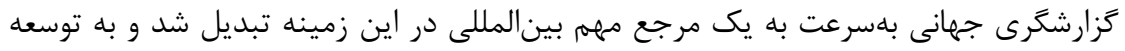

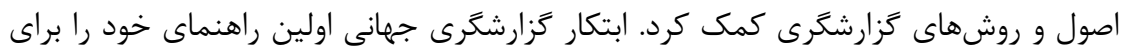

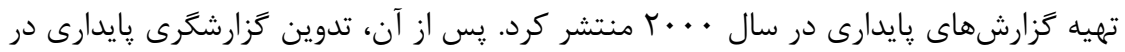

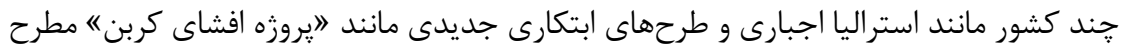

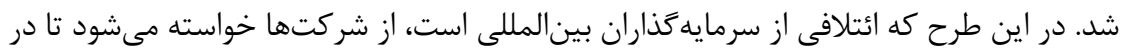
مورد نقش، سهم و خطمشىهاى خود در خصوص تغيير اقليم اطلاعاتى را افشا كنند. هرجند

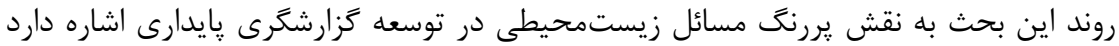

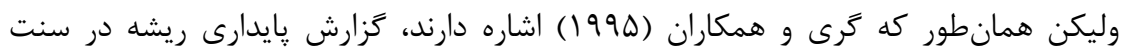

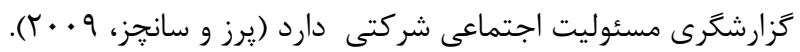

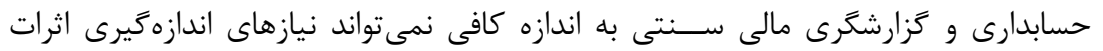

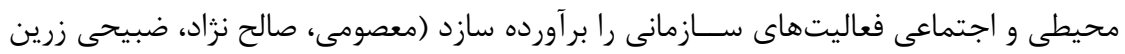

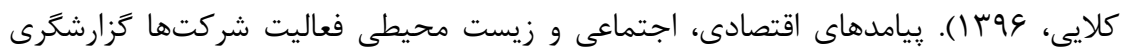

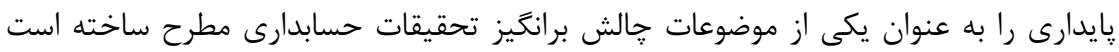

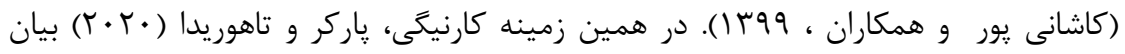

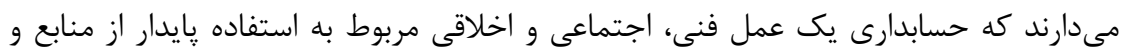

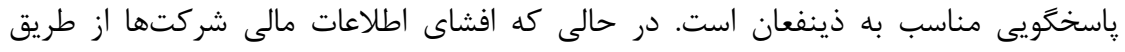

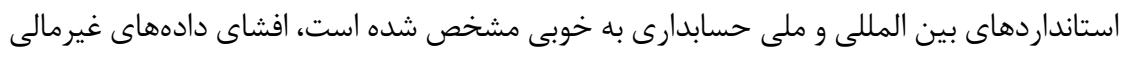

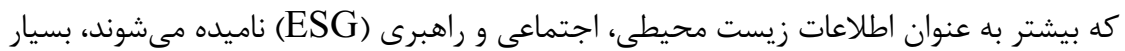
سازماندهى نشده و بدون استانداردهاى يذيرفته شده جهانى قابل ارجاع است. با اين حال تعال تعهد

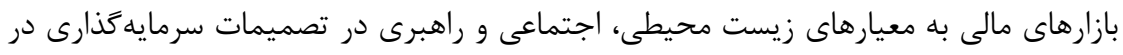

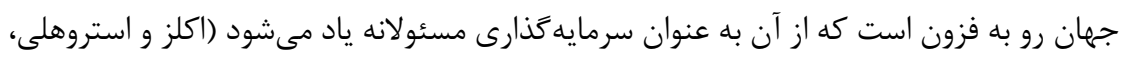




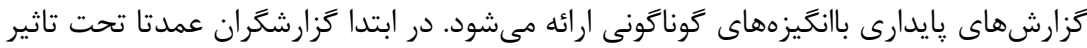

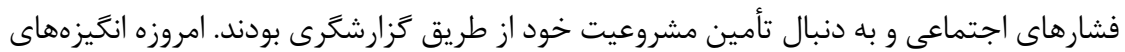

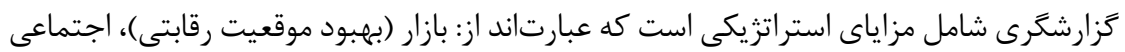
(رفع קالشهاى مربوط به ذينفعان)، سياسى (كاهش قوانين و فشار سياسى) و پاسخكويى (ايفاى

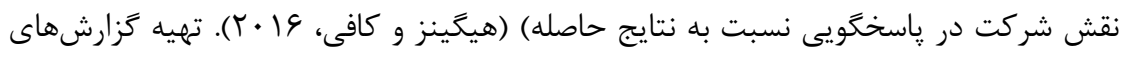

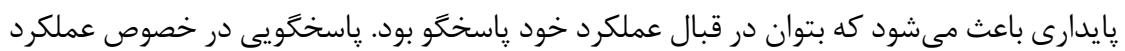

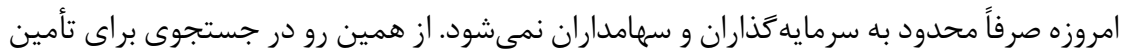

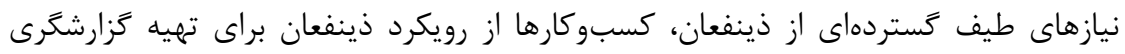

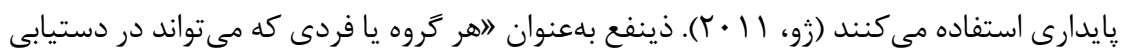

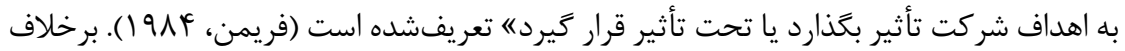

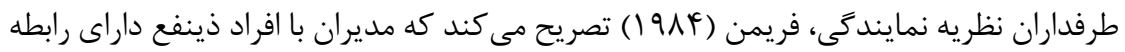

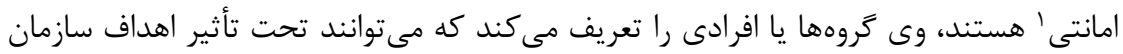

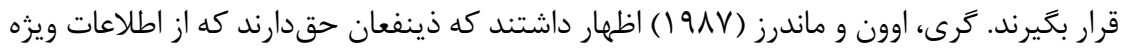
براى اخذ تصميمات خاص بهرهمند شوند.

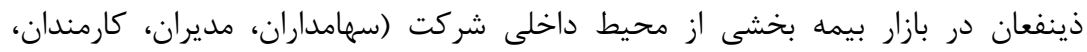

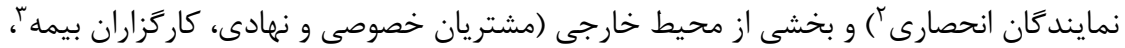

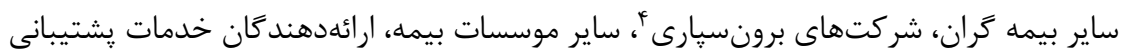

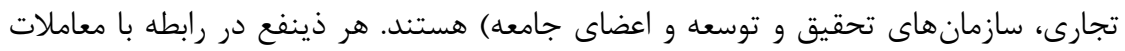
خود با يك شركت بيمه داراى الزامات و انتظارات خاصى است. اولويت بيمه كَران بايد توسعهاي

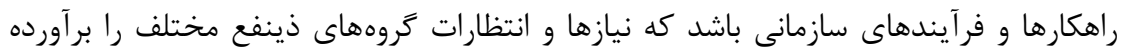

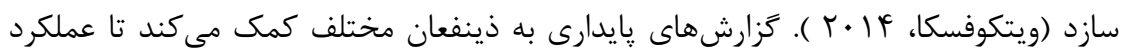
بيمه را موردسنجش قرار دهند و از آن براى اتخاذ تصميمات بهينه استفاده نمايند. كزارشكرى

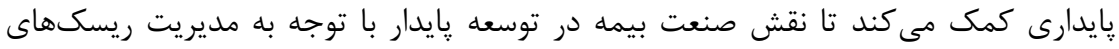

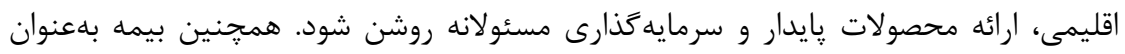

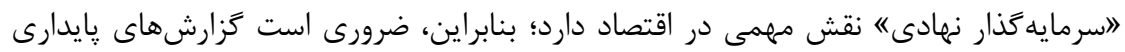

${ }^{1}$ fiduciary

${ }^{2}$ exclusive agents

${ }^{3}$ insurance brokers

${ }^{4}$ outsourcing companies 


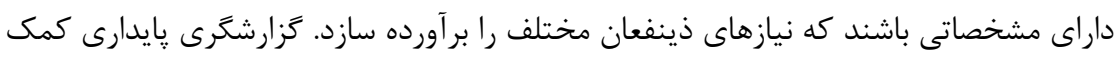

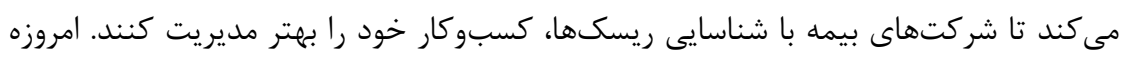

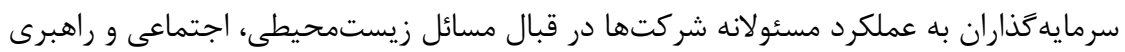

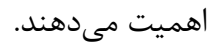

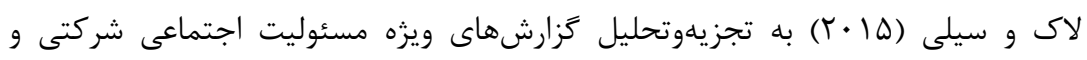

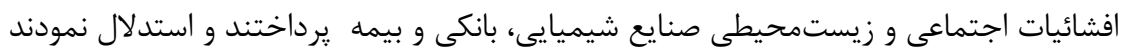

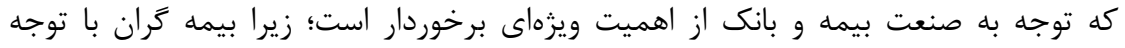

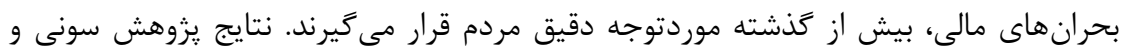

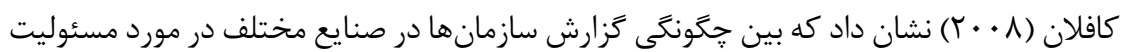

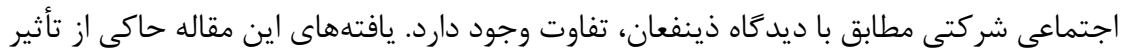

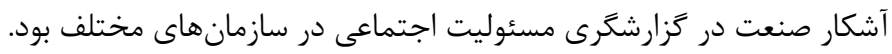

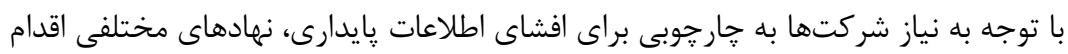

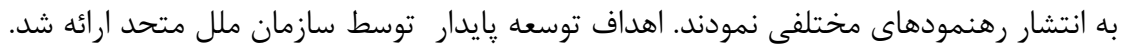

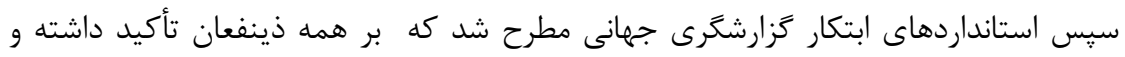

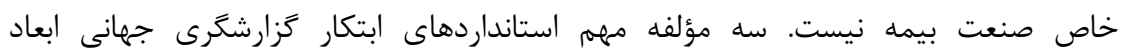

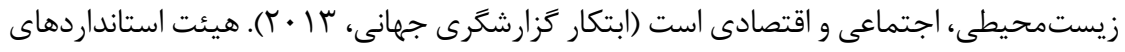

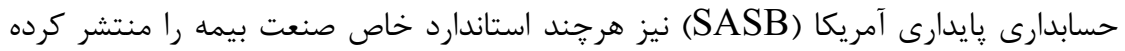

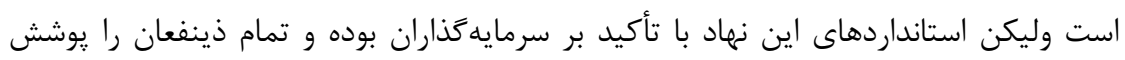

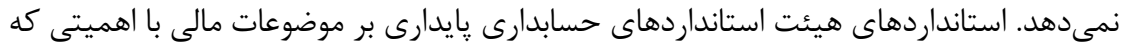

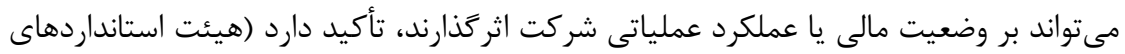

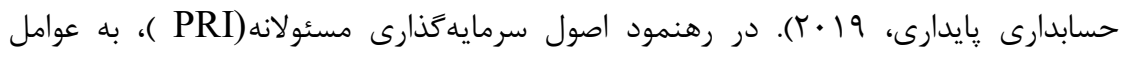
زيستمحيطى، اجتماعى و راهبرى در فرايند سرمايه گذارى توجه مى شود. رهنمود اصول بيمه

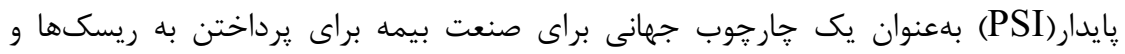

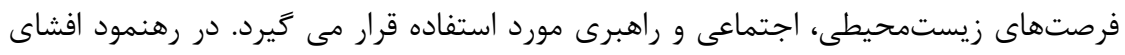

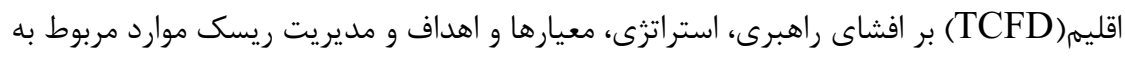

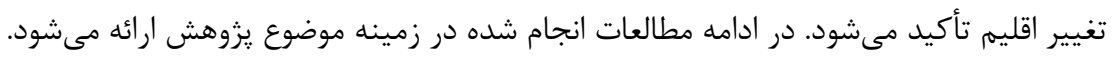

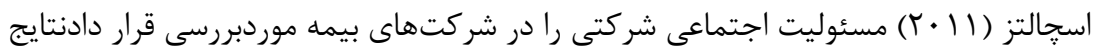

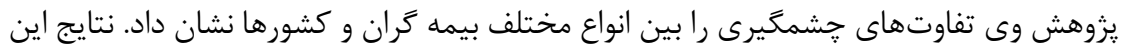

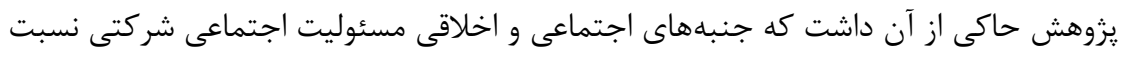

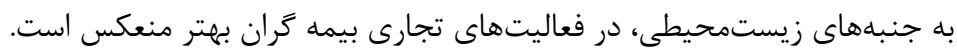




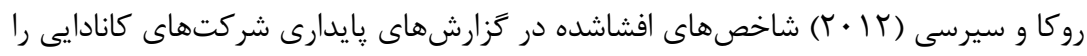

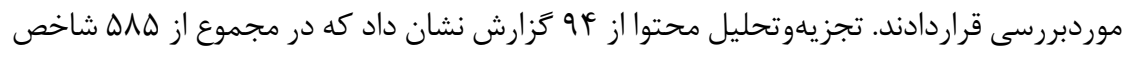
مختلف در كزارشها استفادهشده است.

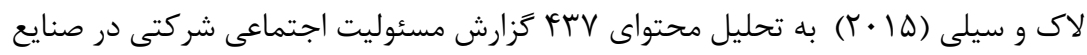

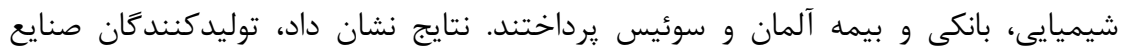

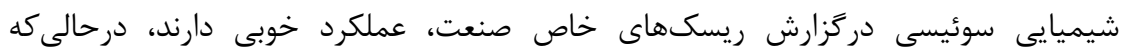

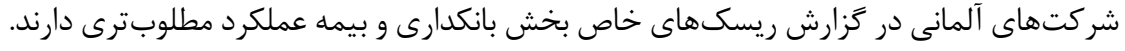

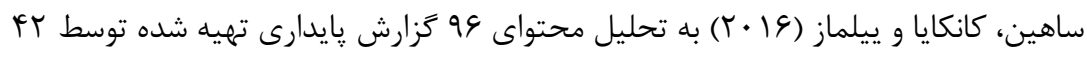

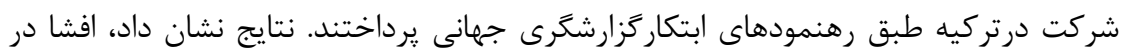

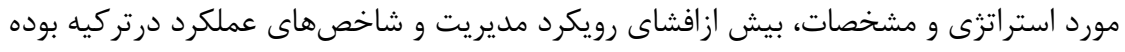

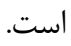

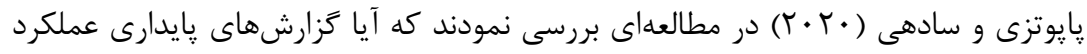

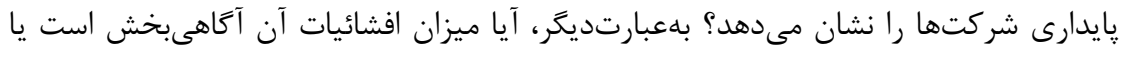

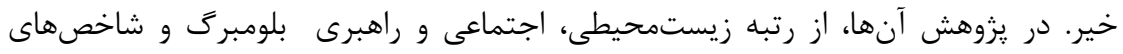

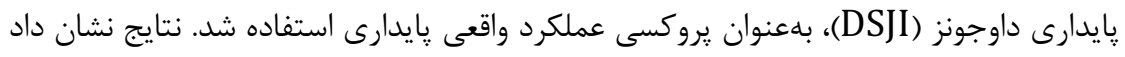

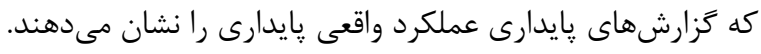

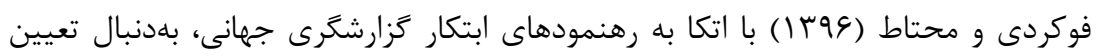

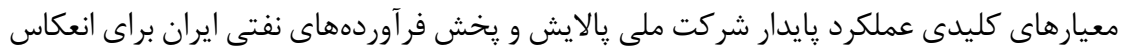

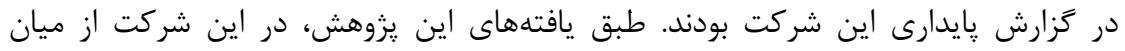

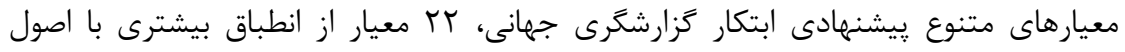

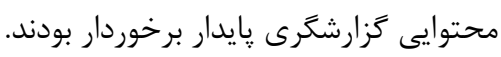

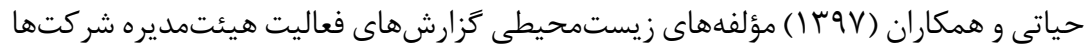

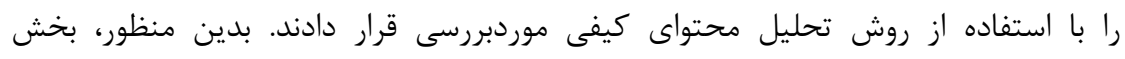

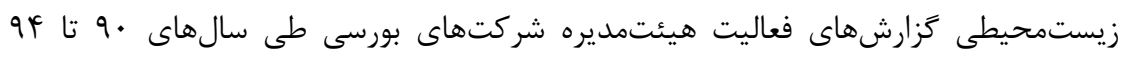

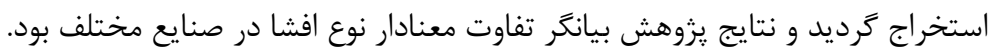

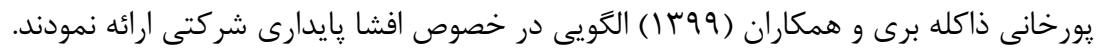

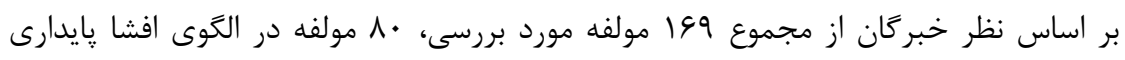
شركتى لحاظ شد. 


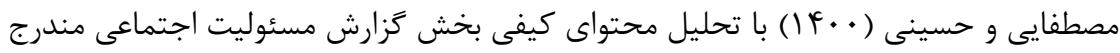

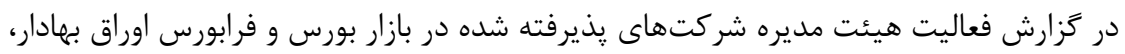

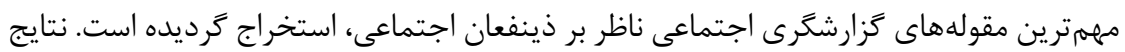
نشان داد تفاوت نوع افشاء در سطح صنايع انتخابى معنادار بودئ

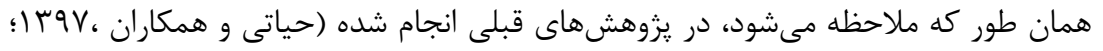

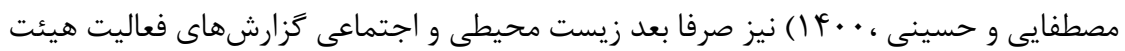

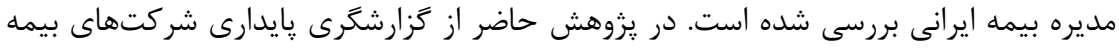

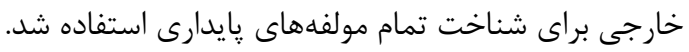

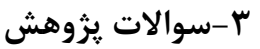

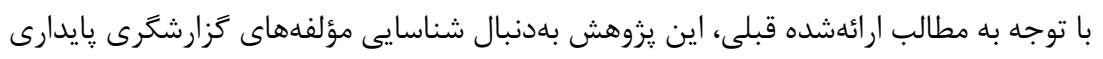

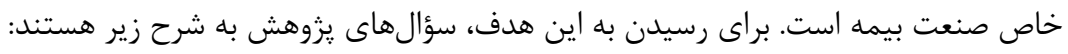

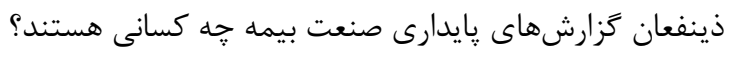

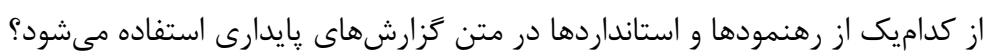

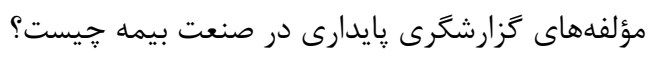

\section{F}

محققان در زمينه حسابدارى زيستمحيطى و اجتماعى، عموماً از تحليل محتوا بهاعنوان روش

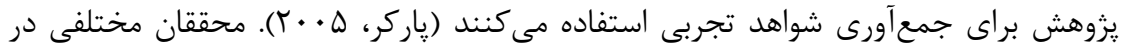

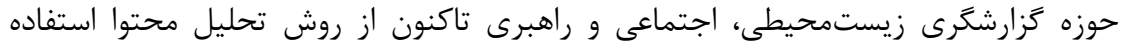

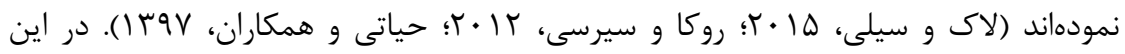

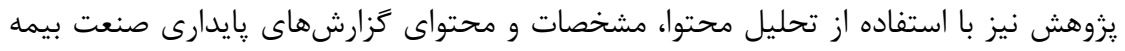

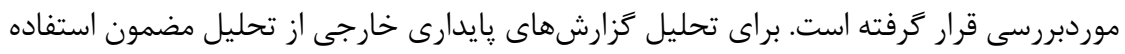

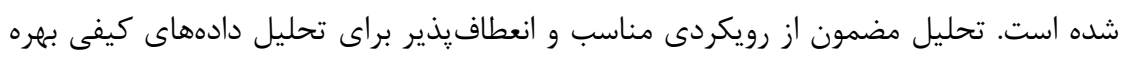

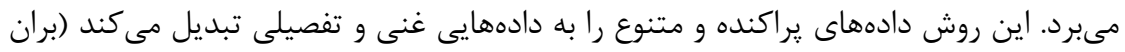

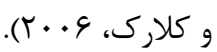

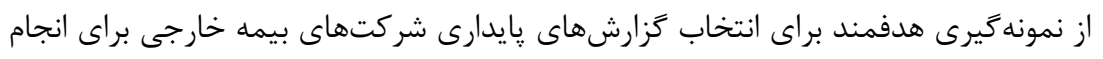

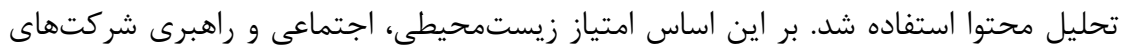

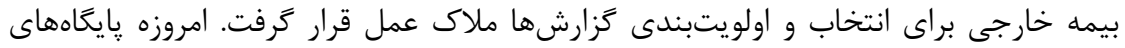

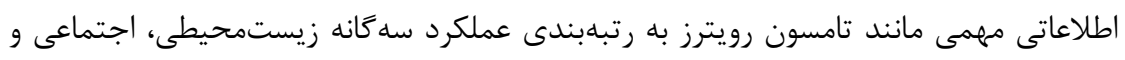


راهبرى شركتها مى يردازند. بانكهاى اطلاعاتى كه از جندين سال بيش ايجادشده است، اين

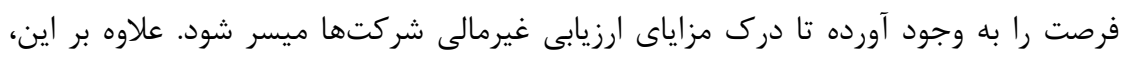

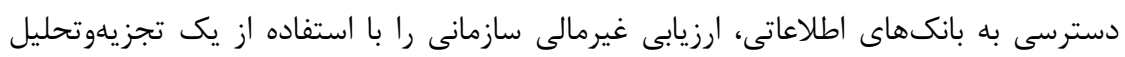

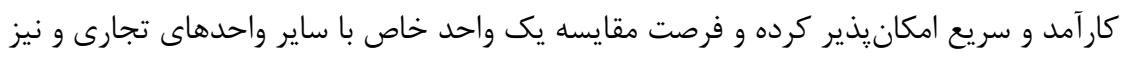

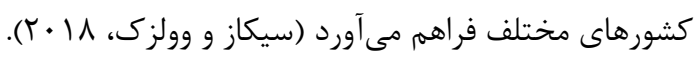

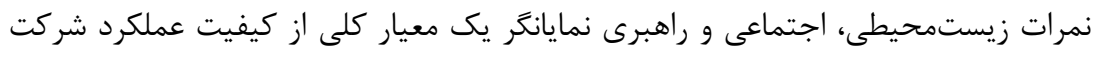

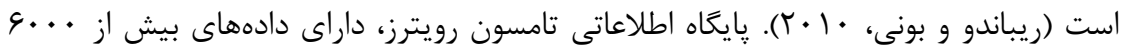

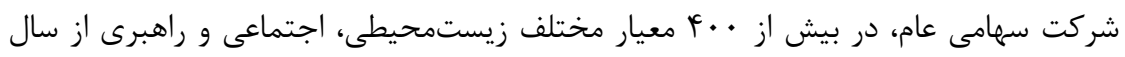

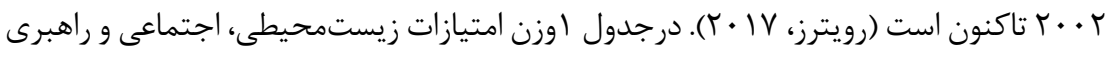

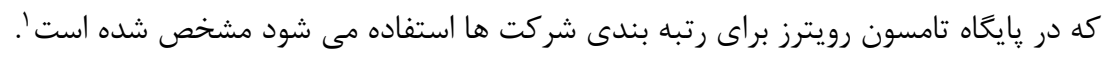

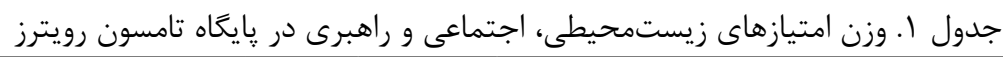

\begin{tabular}{|c|c|c|c|c|}
\hline وزن ستون & وزن & دراخصها & دسته & مؤلفه \\
\hline \multirow{3}{*}{$11 \%+1 r \%+11 \%$} & $11 \%$ & 19 & | & \multirow{3}{*}{ 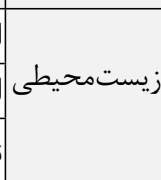 } \\
\hline & $1 r \%$ & tr & |انتشار كاز كلخانهاى & \\
\hline & $11 \%$ & $r$. & 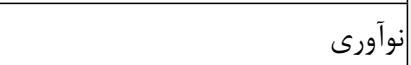 & \\
\hline \multirow{4}{*}{$\begin{array}{l}1 \varsigma \%+\varphi, \Delta \%+\wedge \%+\gamma \\
\%\end{array}$} & $19 \%$ & rq & |نيروى كار & \multirow{4}{*}{ 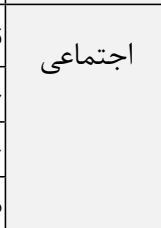 } \\
\hline & $\varphi, \Delta \%$ & $\Lambda$ & حقوق بشر & \\
\hline & $\wedge \%$ & if & جامعه محلى & \\
\hline & $\vee \%$ & ir & محصولات مسئولانه & \\
\hline \multirow[t]{3}{*}{$19 \%+v \%+r, \downarrow \%$} & $19 \%$ & ry & مديريت & \multirow{3}{*}{ راهبرى } \\
\hline & $\vee \%$ & it & سمامداران & \\
\hline & $\varphi, \Delta \%$ & $\wedge$ & استراترى مسئوليت اجتماعى شركتى & \\
\hline$\%$ & 1 & IVA & - & جمع \\
\hline
\end{tabular}

منبع: رويترز، 19.

بر اساس جدول(1)، هر يكى از مؤلفهاى زيستمحيطى، اجتماعى و راهبرى از دستههاى روناى

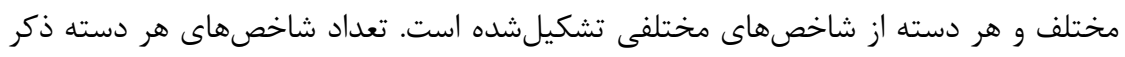

\footnotetext{
${ }^{1} \mathrm{https}: / /$ www.thomsonreuters.com/
} 
شده در جدول ا، تعيينكننده وزن ستون مربوطه است. براى محاسبه نمرات مقولههاى

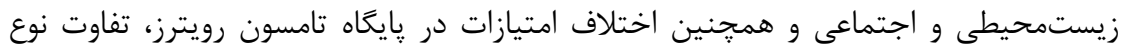

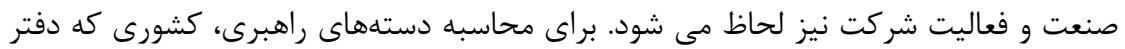

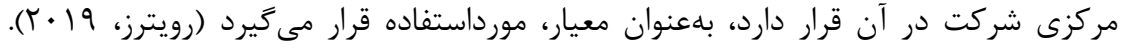

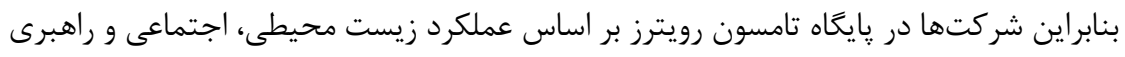

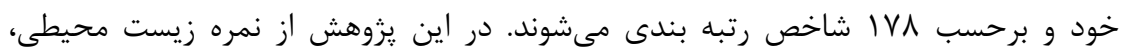
اجتماعى و راهبرى شركت براى انتخاب شركتهاى مورد تحليل استفاده شد.

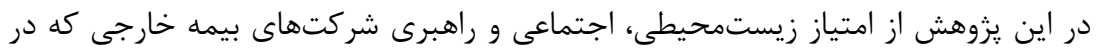

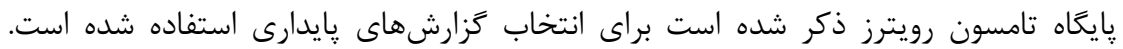

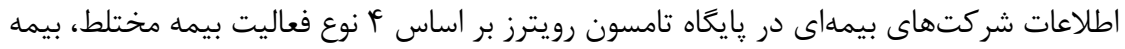

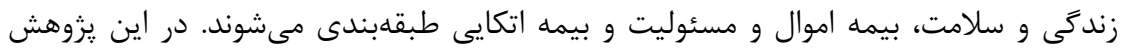

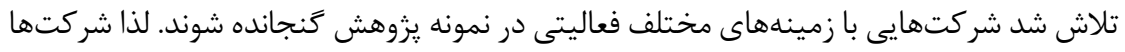
بر اساس امتياز يايدارىدر أزمينه فعاليت اولويتبندى شده و آنهائى كه بالاترين امتياز بايدارى

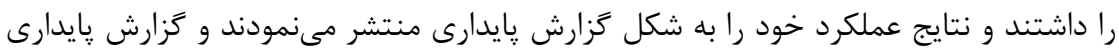

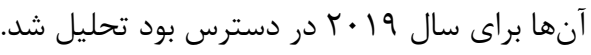

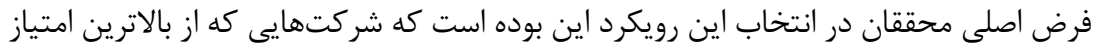

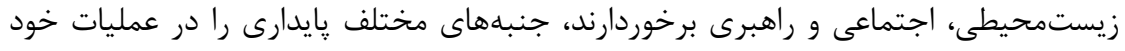

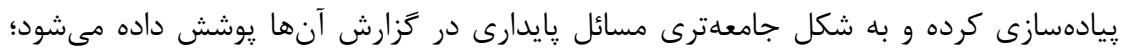

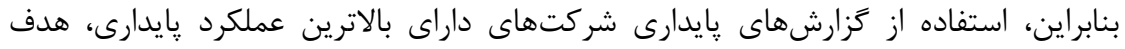

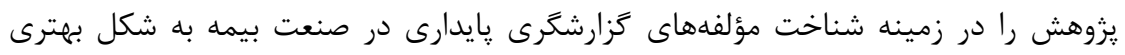
برآورده مىسازد.

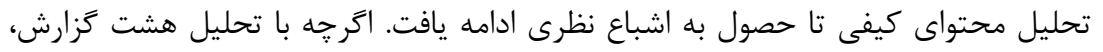

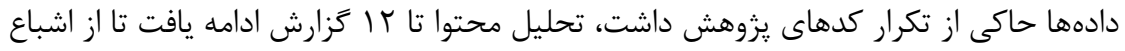

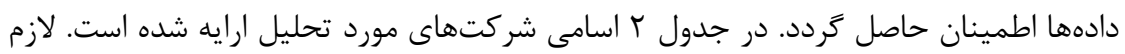
به ذكر است كه امتياز زيست محيطى، اجتماعى و راهبرى شركتهاى مورد تحليل از پإيكاه

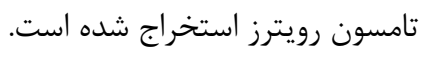




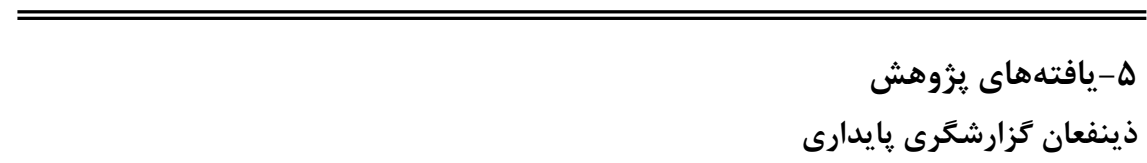

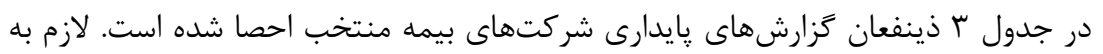

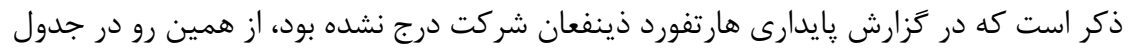
زير اطلاعاتى از هارتفورد نيست.

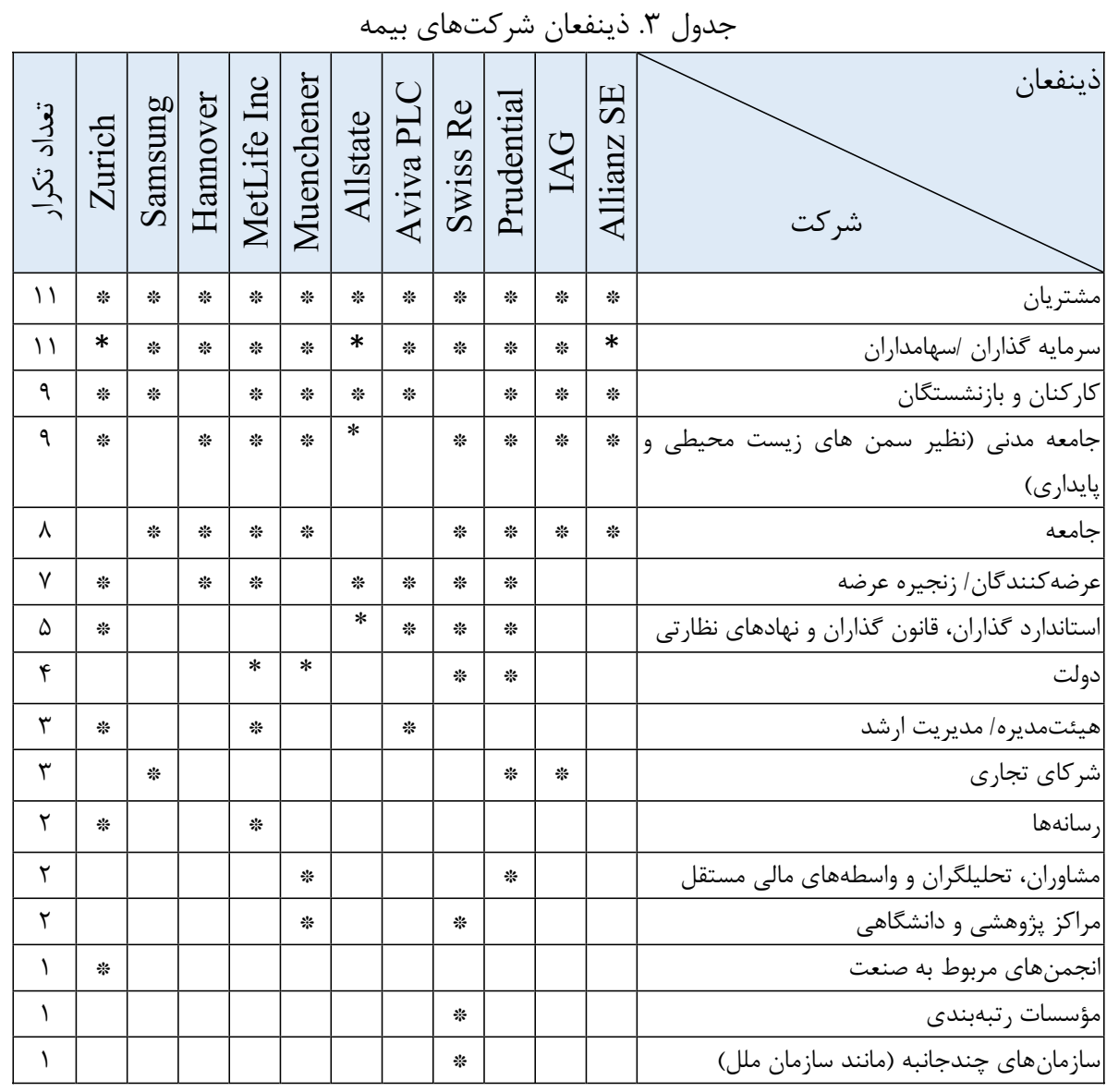

منبع: يافتهاى بزوهش

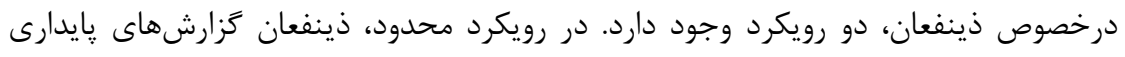

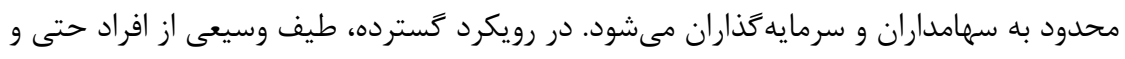


محيطزيست و جامعه بهعنوان ذينفع در نظر گرفته مىشود. همانطور كه در جدول فوق مشخص

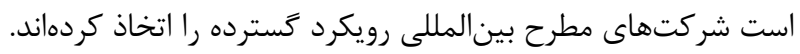

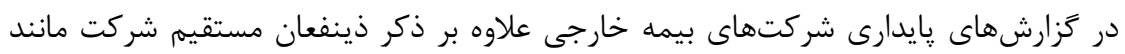

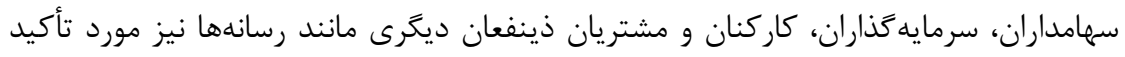

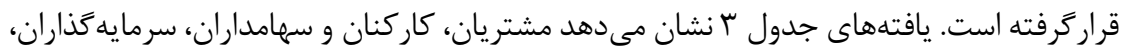
عرضه كنند

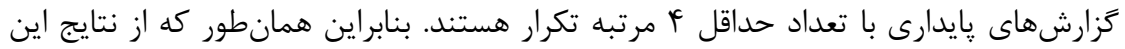

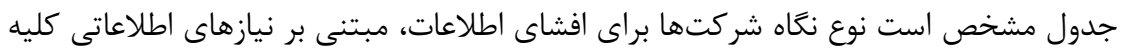
ذينفعان است.

\section{نوع استانداردها، رهنمودها و افشائيات مورد تأكيد}

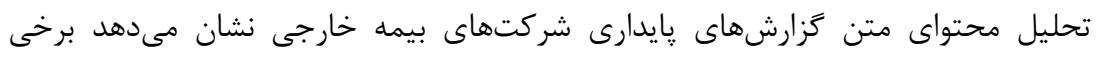

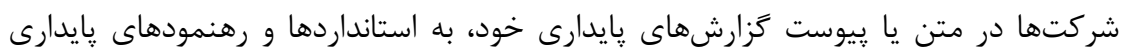

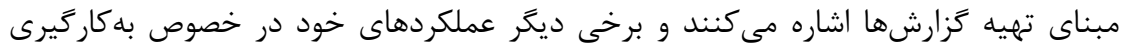

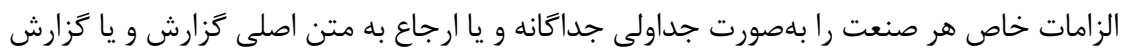

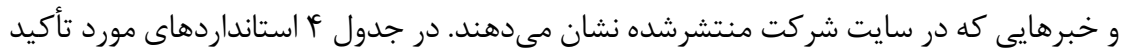

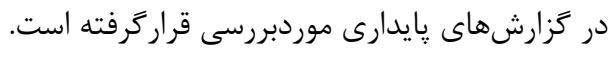

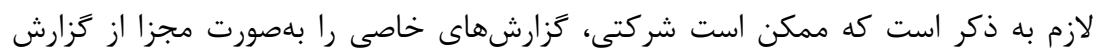

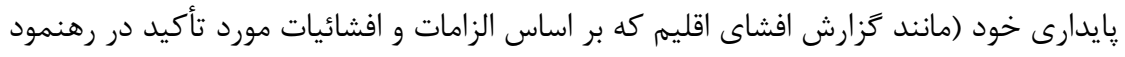

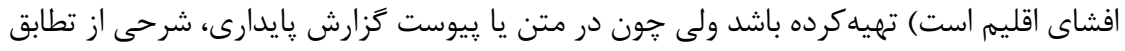

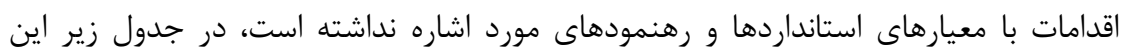

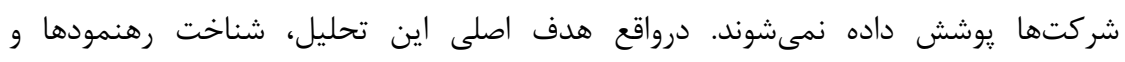

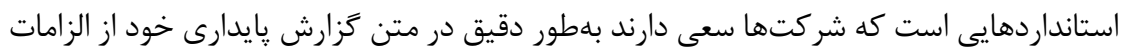

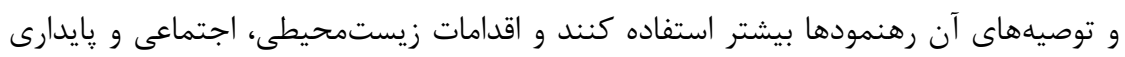

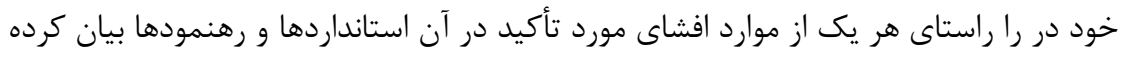

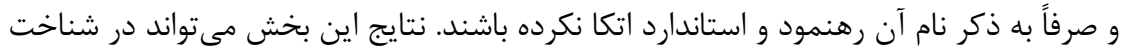

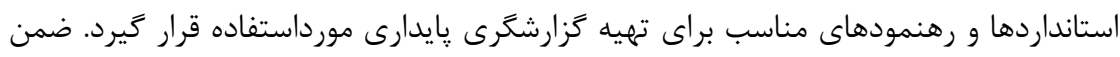

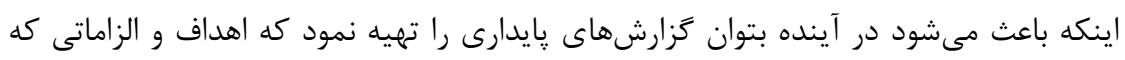
مدنظر نهادهاى مختلف است را بر آورده سازد. 
دوفصلنامه حسابدارى ارزشى و رفتارى، سال ششه، شماره يازدهم، بهار و تابستان + +ع|

\begin{tabular}{|c|c|c|c|c|c|c|c|}
\hline \multicolumn{8}{|c|}{ جدول fا. نوع استانداردها، رهنمودها و افشائيات مورد تأكيد } \\
\hline تعراد & اقشاى اقليم & $\begin{array}{l}\text { توسعده } \\
\text { (يايدار } \\
\text { (SDG) }\end{array}$ & $\begin{array}{l}\text { بيمه } \\
\text { بايدار } \\
\text { (PSI) }\end{array}$ & 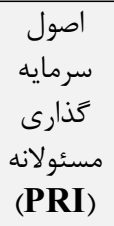 & 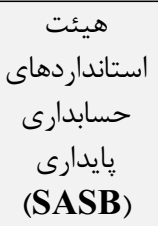 & $\begin{array}{c}\text { ززارشخرى ابتكارى } \\
\text { جهانى } \\
\text { (GRI) }\end{array}$ & هر \\
\hline r & * & * & & & & * & Allianz SE \\
\hline$r$ & $*$ & $*$ & & & & * & IAG \\
\hline r & $*$ & & & & * & $*$ & Prudential \\
\hline 1 & & * & & & & & Swiss Re \\
\hline • & & & & & & & Aviva \\
\hline$r$ & & * & & & & * & Allstate \\
\hline$r$ & & $*$ & & $*$ & & * & Muenchener \\
\hline • & & & & & & & Hartford \\
\hline f & $*$ & * & & & $*$ & $*$ & MetLife Inc \\
\hline 1 & & & & & & $*$ & Hannover \\
\hline$r$ & & * & & & & * & Samsung \\
\hline r & & * & * & & & * & Zurich \\
\hline- & F & $\Lambda$ & 1 & 1 & r & 9 & 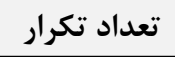 \\
\hline
\end{tabular}

\section{منبع: يافتههاى يزوهش}

همانطور كه اشاره شد، با توجه به اتخاذ رويكرد گسترده ذينفعان توسط شركتهاى بيمه

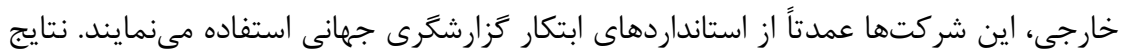
جدول f أشان مى جدهد كه عمده شركتها از استانداردهاى ابتكار زَارشخرى جهانى استفاده كردهاند و شركتهاى محدودى نيز سعى داشتهاند در جداولى مجزا، انطباق عملكرد خود با

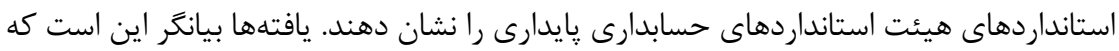
در نمونه اين يزوهش، فقط شركتهاى آمريكايى جداول تطابق با استانداردهاى هيئت استانداردهاى حسابدارى يايدارى داشتهاند كه دليل اصلى آن هم اين است كه هيئت

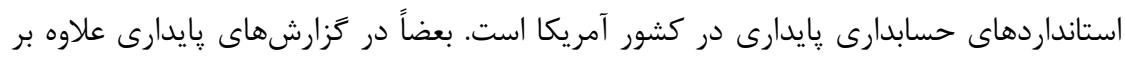

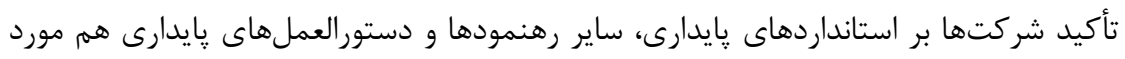

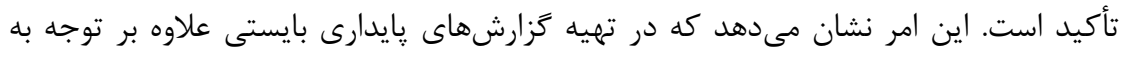
استانداردهاى كَزارشخَى يايدارى، به رهنمودهايى جون افشاى اقليم، سرمايه گذارى مسئولانه و

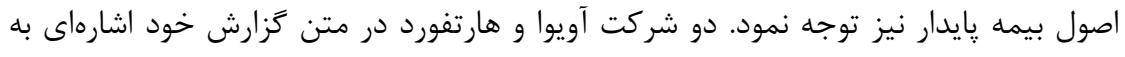
رهنمود خاصى نكردهاند. هرجند هارتفورد جدول تطابق اقدامات با استانداردهاى ابتكار 
كزارشكرى جهانى در متن گزارش پايدارى خود ندارد اما در كزارشهايى مجزا، اقدامات خود در

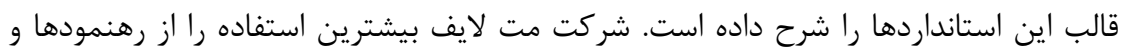
استانداردهاى پايدارى كرده است.

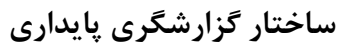

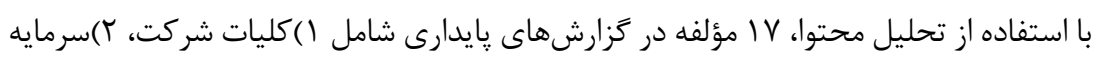

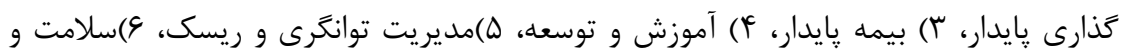

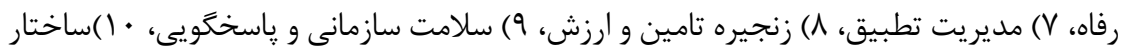

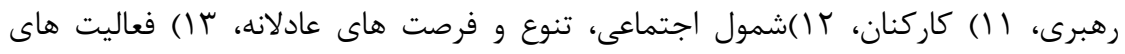

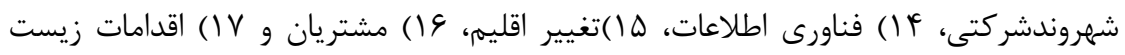

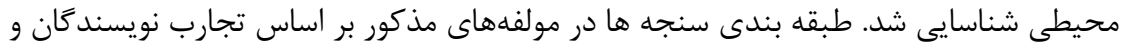

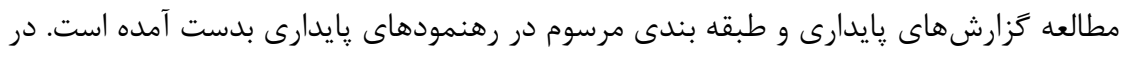

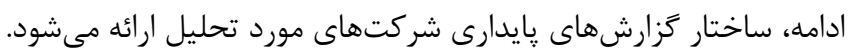

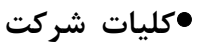
تمام كزارشهاى يايدارى به معرفى فعاليت شركت، سال تهيه كزارش و..... مى يردازند. درجدول

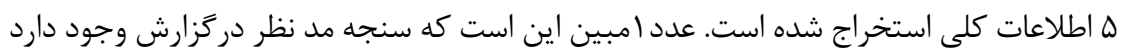

\begin{tabular}{|c|c|c|c|c|c|c|c|c|c|c|c|c|c|c|}
\hline \multicolumn{15}{|c|}{ جدول ) } \\
\hline$\dot{2}$ & : & 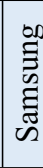 & 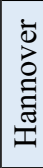 & 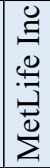 & 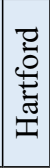 & \begin{tabular}{|c|}
$\bar{v}$ \\
$\bar{d}$ \\
$\bar{v}$ \\
$\bar{v}$ \\
$\bar{d}$ \\
$\Sigma$
\end{tabular} & 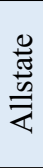 & 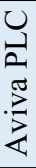 & $\frac{2}{n}$ & 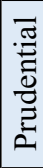 & $\leq$ & $\begin{array}{l}\text { 岕 } \\
\text { N } \\
\stackrel{\Xi}{\Xi} \\
\end{array}$ & سنجه & رديف| \\
\hline 11 & 1 & 1 & 1 & 1 & 1 & 1 & 1 & & 1 & 1 & 1 & 1 & ي يام مديرعامل يا رئيس هيئت مديره & 1 \\
\hline 1. & 1 & 1 & 1 & 1 & 1 & 1 & & & 1 & 1 & 1 & 1 & معرفى كلى شركت & r \\
\hline 11 & 1 & 1 & 1 & 1 & & 1 & 1 & 1 & 1 & 1 & 1 & 1 & توصيف ذينفعان شركت & r \\
\hline 9 & & 1 & 1 & & 1 & 1 & 1 & 1 & 1 & 1 & 1 & & وضعيت كلى حساب ها و صورت هاى & r \\
\hline 1. & 1 & 1 & 1 & 1 & & 1 & 1 & & 1 & 1 & 1 & 1 & نقشه اهميت بِايدارى & $\Delta$ \\
\hline ir & 1 & 1 & 1 & 1 & 1 & 1 & 1 & 1 & 1 & 1 & 1 & 1 & مشخصات كلى ززارشگرى & 9 \\
\hline
\end{tabular}




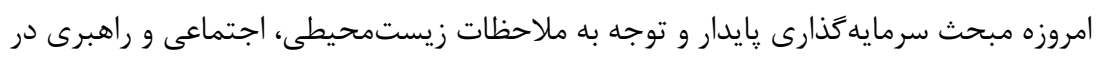

سرمايه گذارىها و نيز مالكيت فعال در شركتهاى سرمايه يذير مورد تأكيد است. در صفحس

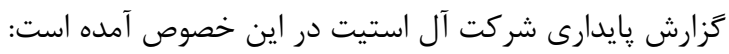

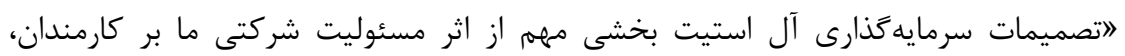

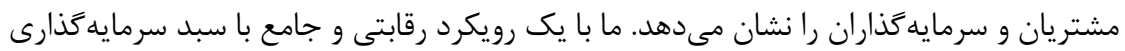

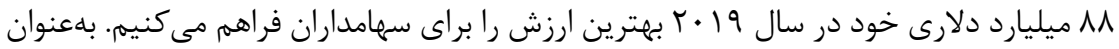

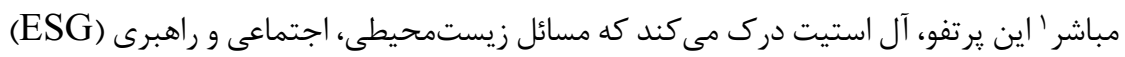

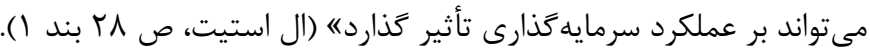

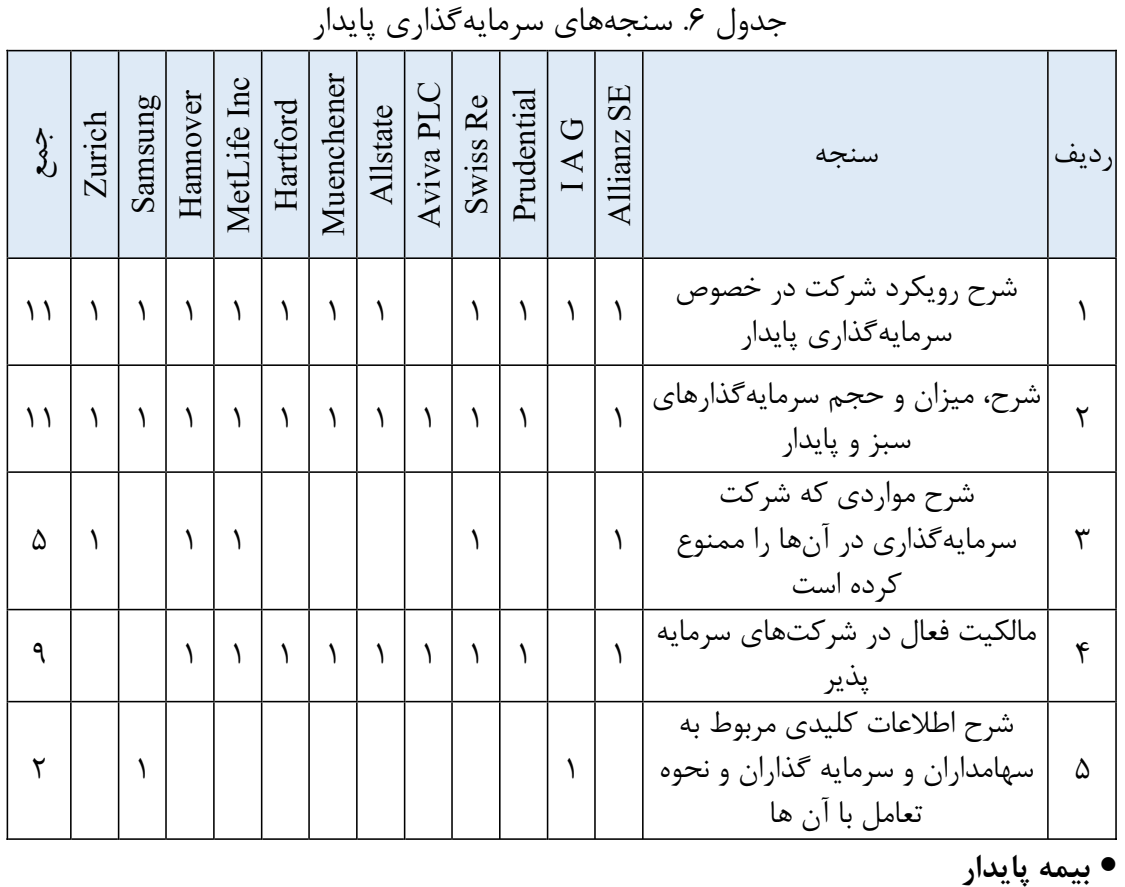

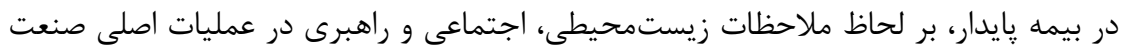

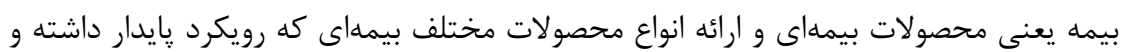

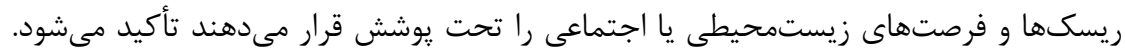
در جدول V سنجهاى بيمه پِايدار ذكر شده است.

${ }^{1}$ steward 


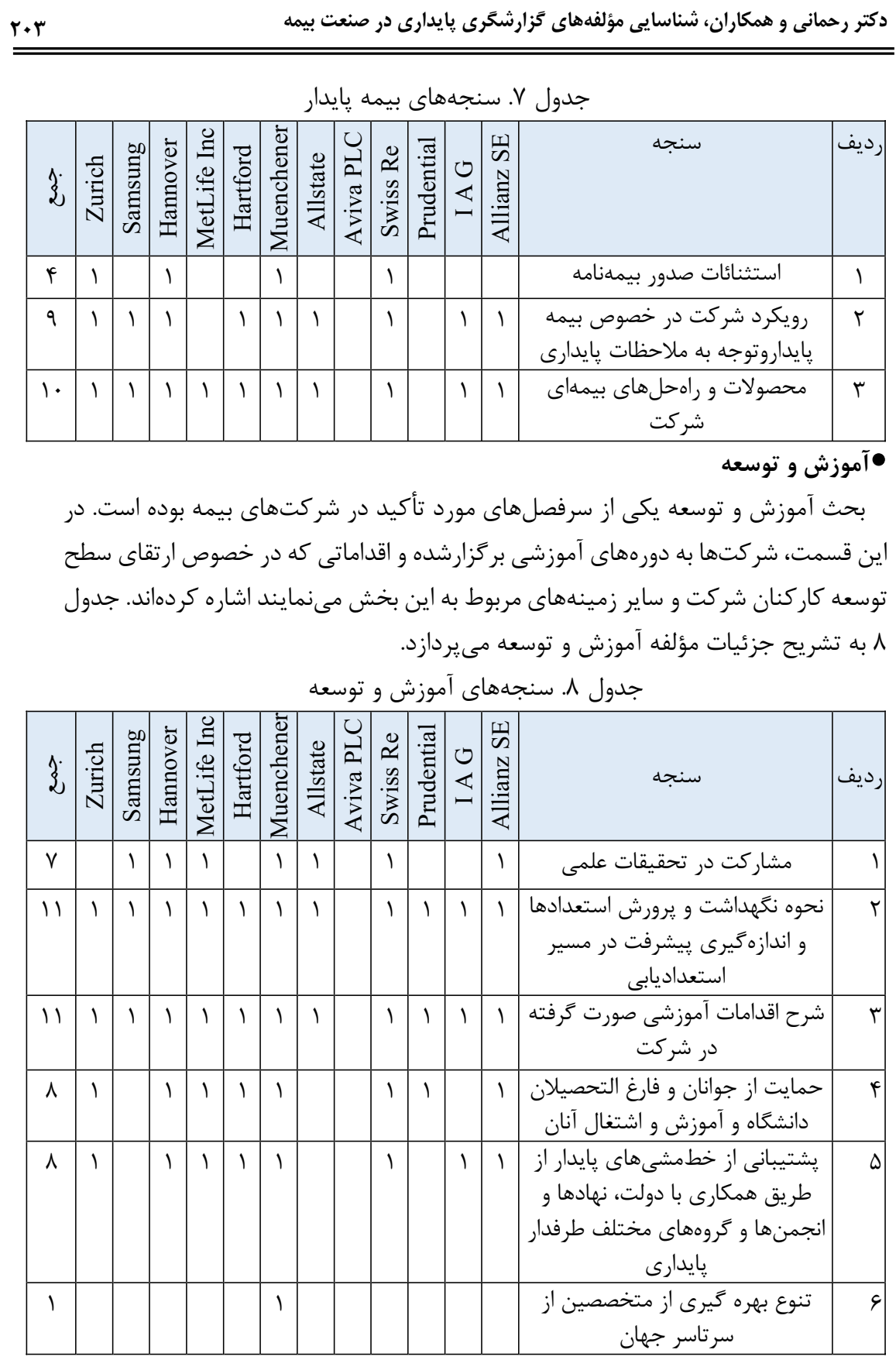




\section{•مديريت توانگرى و ريسك}

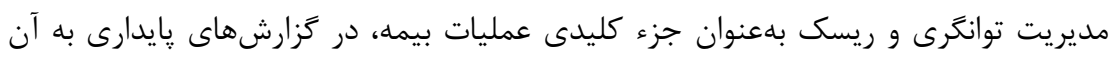

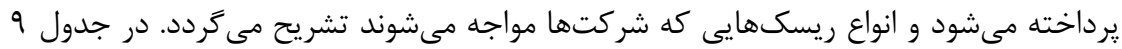
سنجهاى مديريت ريسك بيان شده است. جدول 9.

\begin{tabular}{|c|c|c|c|c|c|c|c|c|c|c|c|c|c|c|}
\hline 3 & 를 & 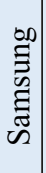 & 离 & 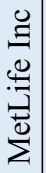 & 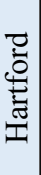 & 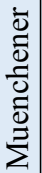 & 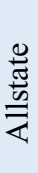 & $\begin{array}{l}u \\
-1 \\
2 \\
\pi \\
z \\
z \\
z\end{array}$ & $\begin{array}{l}\overrightarrow{0} \\
\infty \\
\infty \\
\infty \\
\infty \\
\infty\end{array}$ & 茎 & $\begin{array}{l}\circlearrowleft \\
\longleftarrow \\
\smile\end{array}$ & 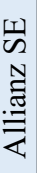 & سنجه & رديف \\
\hline 1. & 1 & 1 & 1 & 1 & & 1 & 1 & & 1 & 1 & 1 & 1 & سنجش وضعيت مديريت توانخرى و & 1 \\
\hline 11 & 1 & 1 & 1 & 1 & 1 & 1 & 1 & & 1 & 1 & 1 & 1 & شرح مديريت انواع ريسكهاى كسبوكار شركت & $r$ \\
\hline
\end{tabular}
• (15لامت و رفاه محيط كار سالم و امكانات رفاهى نكته كليدى است كه بهخصوص در شرايط همه كيرى بيمارى

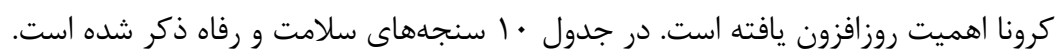

\begin{tabular}{|c|c|c|c|c|c|c|c|c|c|c|c|c|c|c|}
\hline$\xi$ & $\frac{\overline{0}}{\stackrel{0}{\Xi}}$ & 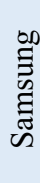 & 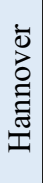 & 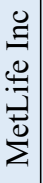 & 总 & 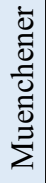 & 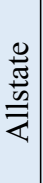 & 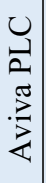 & $\frac{2}{\infty}$ & : & $\begin{array}{l}0 \\
\varangle \\
-\end{array}$ & 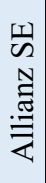 & سنجه & رديف| \\
\hline 11 & 1 & 1 & 1 & 1 & & 1 & 1 & 1 & 1 & 1 & 1 & 1 & 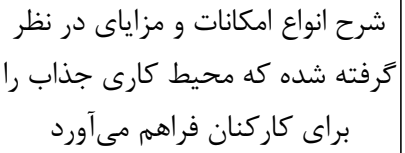 & 1 \\
\hline 9 & 1 & 1 & 1 & 1 & & 1 & 1 & & 1 & 1 & & 1 & سلامت كاركنان و بهرداشت گرفته در خصوص ايمنى & $r$ \\
\hline f & & 1 & 1 & & & 1 & & & 1 & & & & 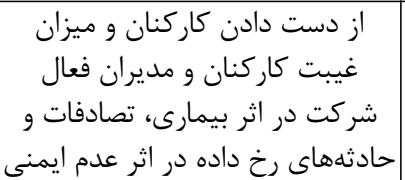 & $r$ \\
\hline
\end{tabular}




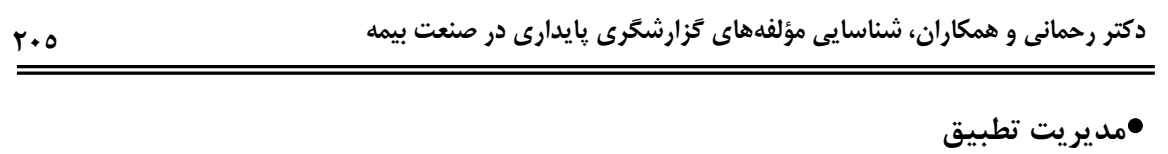

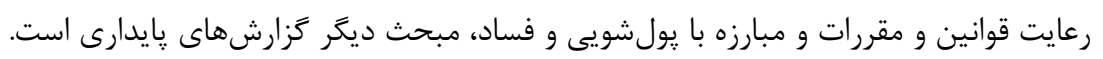
در جدول Iل سنجهاى مرتبط با اين مؤلفه ارائه شده است.

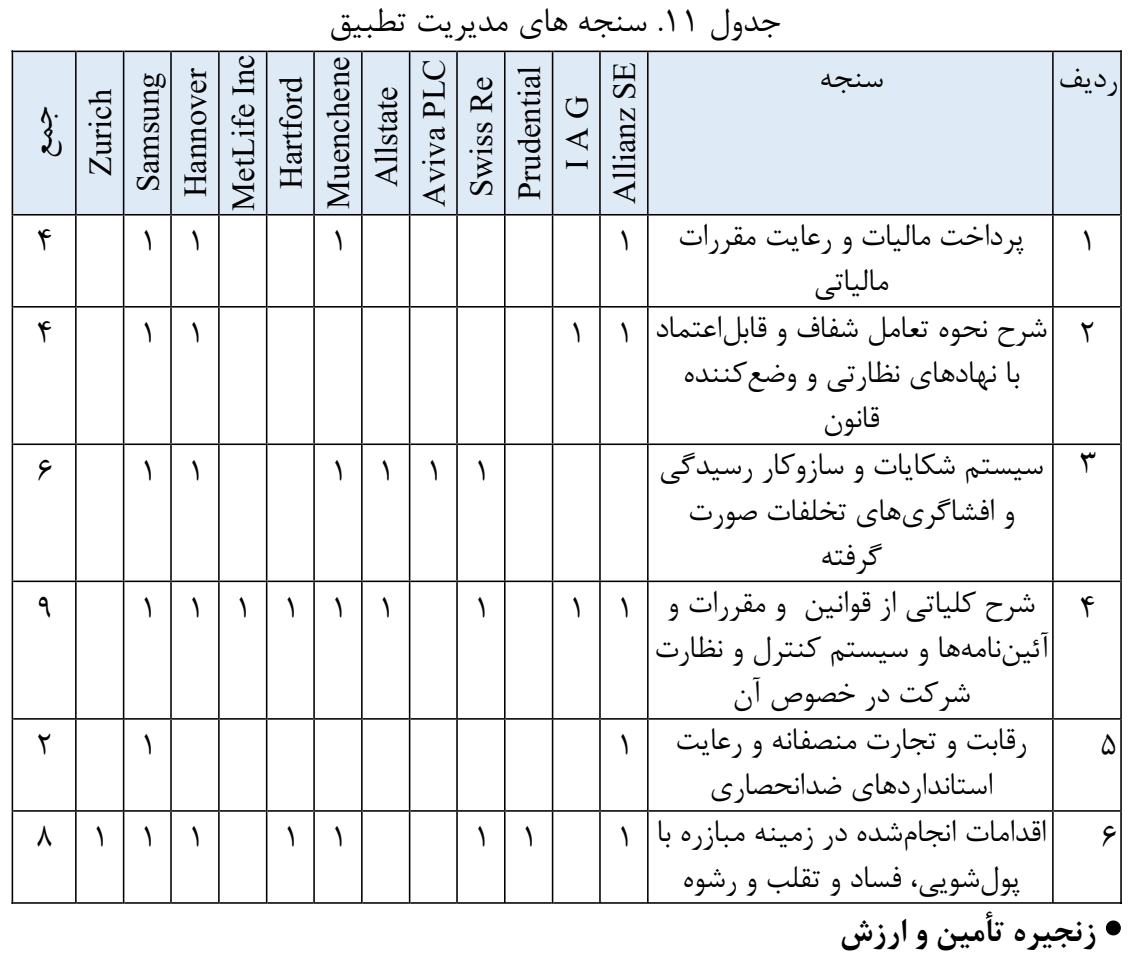

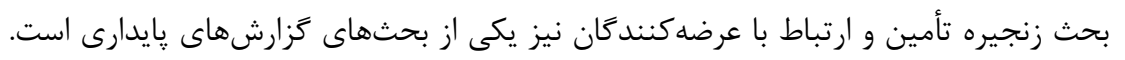

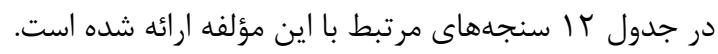

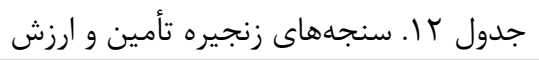

\begin{tabular}{|c|c|c|c|c|c|c|c|c|c|c|c|c|c|c|}
\hline$\xi$ & 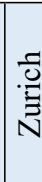 & 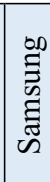 & 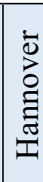 & $\frac{\mathscr{0}}{\stackrel{0}{\overrightarrow{0}}}$ & 믐 & 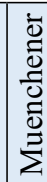 & $\frac{\frac{\pi}{\pi}}{\overline{2}}$ & 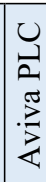 & 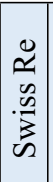 & 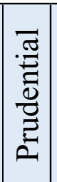 & $\begin{array}{l}\circlearrowleft \\
\longleftarrow\end{array}$ & 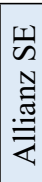 & سنجه & رديف \\
\hline 11 & 1 & & 1 & 1 & 1 & 1 & 1 & 1 & 1 & 1 & 1 & 1 & زنجيره تأمين پايدار و مسئولانه & 1 \\
\hline 1 & & & & & & & & 1 & & & & & تأديه بهان فاكتور صورى يرداخت حساب ها و و و & $Y$ \\
\hline
\end{tabular}




\section{•سلامت سازمانى و ياسخگويى}

در بخش سلامت سازمانى و پاسخكَويى، مواردى كه باعث پاسخخكويى (مانند اطمينان بخشى

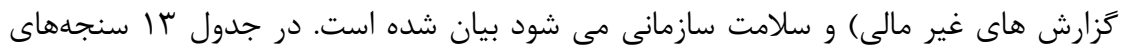
مرتبط با مؤلفه راهبرى ارائه شده است.

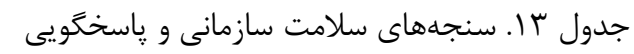

\begin{tabular}{|c|c|c|c|c|c|c|c|c|c|c|c|c|c|c|}
\hline جمع & : & 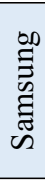 & 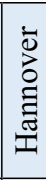 & 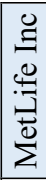 & 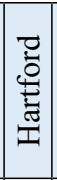 & \begin{tabular}{|l|}
$\bar{\Xi}$ \\
$\bar{\Xi}$ \\
$\frac{\tilde{J}}{0}$ \\
$\bar{\Xi}$ \\
$\stackrel{\Xi}{\Sigma}$ \\
\end{tabular} & 莺 & 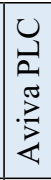 & $\begin{array}{l}\mathscr{2} \\
\infty \\
\infty \\
\infty \\
\infty\end{array}$ & 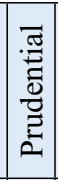 & $\begin{array}{l}0 \\
\varangle \\
\ddots\end{array}$ & 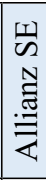 & سنجه & رديف| \\
\hline $1 T$ & 1 & 1 & 1 & 1 & 1 & 1 & 1 & 1 & 1 & 1 & 1 & 1 & |فرهنَسازمانى و اصول و منشور رفتارى آئين رفتار حرفهاى، & 1 \\
\hline 9 & & 1 & 1 & 1 & 1 & 1 & 1 & & 1 & & 1 & 1 & |نغاه كلى به استراترى، اهداف و مأموريت & $r$ \\
\hline 9 & 1 & 1 & 1 & & & 1 & & & 1 & & 1 & & شركت در انواع رتبلبندىهاى مطرح & $r$ \\
\hline$r$ & & & 1 & & & & & & 1 & & 1 & & بر بايدار كسبو منظبود عملكرد مديريت & $f$ \\
\hline$r$ & & & 1 & & & 1 & & & & & & & 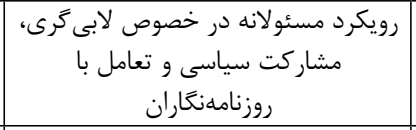 & $\Delta$ \\
\hline V & & 1 & 1 & & 1 & & 1 & & 1 & 1 & 1 & & |رعايت و شرح و نظارت بر اصول و منشور & 4 \\
\hline V & 1 & 1 & 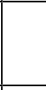 & & & 1 & & 1 & 1 & & 1 & 1 & 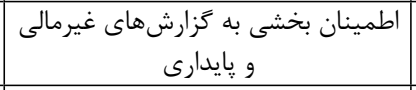 & V \\
\hline 9 & 1 & 1 & 1 & & & & & & 1 & 1 & & 1 & 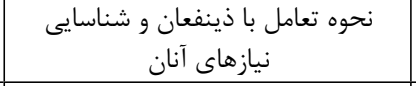 & $\wedge$ \\
\hline f & & & & & & 1 & & & 1 & 1 & & 1 & مدل و خار ¥وب كسبوكار (تجارى) & 9 \\
\hline 1 & & & & & & & & & 1 & & & & خطمشى ها و شرايط همكارى با اشخاص & 1. \\
\hline
\end{tabular}

در بخش ساختار رهبرى، ساختار شركت، نحوه و شرايط عضويت هيئتمديره و ساير مباحث مربوط توضيح داده مىشود. درجدول f ا سنجههاى مرتبط با مؤلفه ساختار هبرى ارائه شده است. 


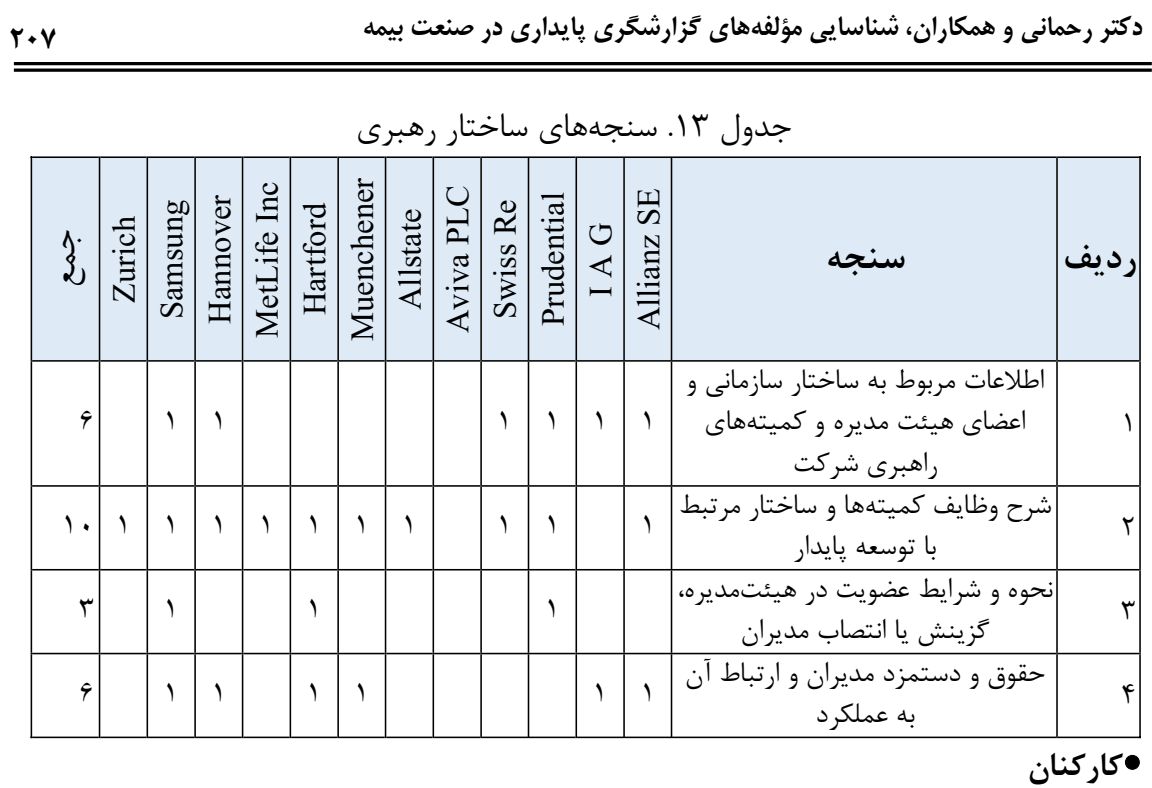

شرح وضعيت و اطلاعات نيروى كارى، سيستم استخدام و ساير اطلاعات مربوط به كاركنان

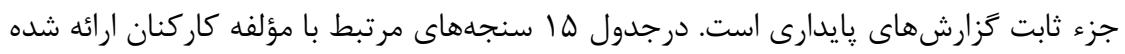

\begin{tabular}{|c|c|c|c|c|c|c|c|c|c|c|c|c|c|c|}
\hline$\xi$ & 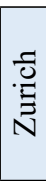 & 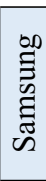 & 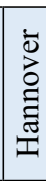 & 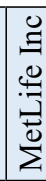 & 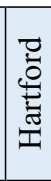 & 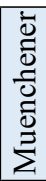 & 莺 & 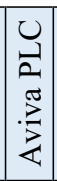 & $\begin{array}{l}0 \\
2 \\
n \\
0 \\
3 \\
0\end{array}$ & 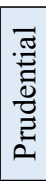 & $\underset{\Xi}{\longleftarrow}$ & $\begin{array}{l}\text { II } \\
\text { N } \\
\stackrel{N}{\Xi} \\
\stackrel{\Xi}{Z}\end{array}$ & سنجه & رديف \\
\hline 11 & 1 & 1 & 1 & 1 & & 1 & 1 & 1 & 1 & 1 & 1 & 1 & اطلاعات كليدى مربوط كاركنان & 1 \\
\hline f & & 1 & 1 & & & 1 & & & & & & 1 & نحوه ارتقا و توسعه شغلى كاركنان & t \\
\hline$\Delta$ & & 1 & & 1 & & 1 & 1 & & & & & 1 & برنامه مديريت عملكرد كاركنان & r \\
\hline 9 & & 1 & 1 & 1 & 1 & 1 & 1 & & 1 & 1 & & 1 & سيستم حقوق و پاداداش و مزاياى & f \\
\hline$\checkmark$ & & 1 & 1 & 1 & & 1 & & & 1 & 1 & & 1 & 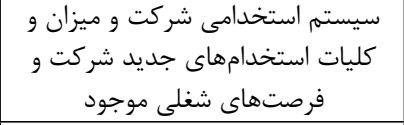 & $\Delta$ \\
\hline r & & & 1 & & & 1 & & & & & & & فرهنَ سازمانى مسئولت يذير و و و & q \\
\hline f & 1 & & 1 & & & 1 & 1 & & & & & & منشور اخلاقى و رفتارى مدير و كاركنان & V \\
\hline 1 & & & & & & & & & 1 & & & & بازخوردهاى دريافتى از مديران شركت & $\wedge$ \\
\hline$r$ & & & 1 & & & & & & & & & 1 & روند تغيير نيازها و تركيب نيروى كار & 9 \\
\hline
\end{tabular}


دوفصلنامه حسابدارى ارزشى و رفتارى، سال ششم، شماره يازدهم، بهار و تابستان +. عا

\begin{tabular}{|c|c|c|c|c|c|c|c|c|c|c|c|c|c|c|}
\hline$\xi$ & $\stackrel{\frac{c}{0}}{\stackrel{0}{\Xi}}$ & 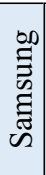 & 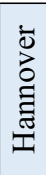 & 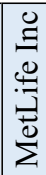 & 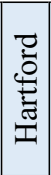 & 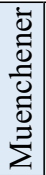 & 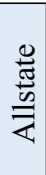 & $\frac{1}{3}$ & $\begin{array}{c}0 \\
2 \\
0 \\
.0 \\
3 \\
n \\
n\end{array}$ & 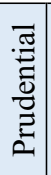 & $\begin{array}{l}\circlearrowright \\
\longleftarrow\end{array}$ & 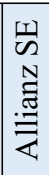 & سنجه & رديف \\
\hline$r$ & & 1 & 1 & & & & & & 1 & & & & 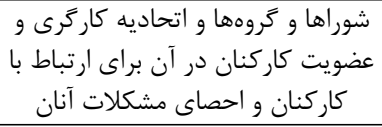 & 1. \\
\hline 11 & 1 & 1 & 1 & 1 & 1 & 1 & 1 & 1 & 1 & 1 & & 1 & رضايت مندى كاركنان و دريافت & 11 \\
\hline
\end{tabular}

• تنوع، شمول اجتماعى و فرصتهاى عادلانه

امروزه توجه به حقوق زنان و مباحثى مانند بهرهمندى عادئ عادلانه از حقوق و مزاياى شغلى مباد مبحث

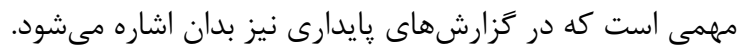

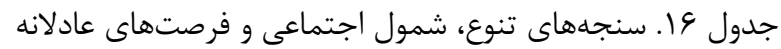

\begin{tabular}{|c|c|c|c|c|c|c|c|c|c|c|c|c|c|c|}
\hline$\xi$ & : & 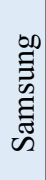 & 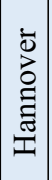 & 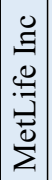 & 它 & 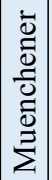 & 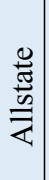 & 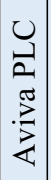 & 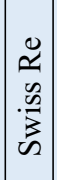 & 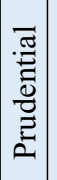 & $\begin{array}{l}\circlearrowleft \\
\longleftarrow \\
\smile\end{array}$ & 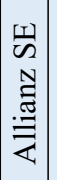 & سنجه & رديف \\
\hline 1. & 1 & 1 & 1 & 1 & 1 & 1 & 1 & & 1 & & 1 & 1 & 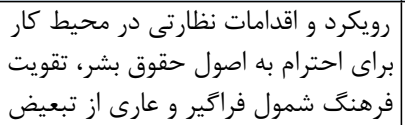 & 1 \\
\hline r & & & & & & & & 1 & & 1 & 1 & & 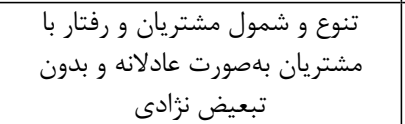 & t \\
\hline IT & 1 & 1 & 1 & 1 & 1 & 1 & 1 & 1 & 1 & 1 & 1 & 1 & شمول اجتماعى و تنوع جنسيتى در كر & r \\
\hline ir & 1 & 1 & 1 & 1 & 1 & 1 & 1 & 1 & 1 & 1 & 1 & 1 & 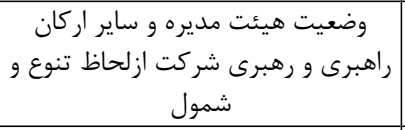 & r \\
\hline r & & & & 1 & & & 1 & & & 1 & & & شمول و تنوع تأمين كنندكان & $\Delta$ \\
\hline$\Delta$ & & 1 & & & & 1 & & & & 1 & 1 & 1 & شمول معلولان در بين كاركنان و & द \\
\hline 1 & & & & & & & & & & & & 1 & شايستهسالارى فراگير بر اساس عملكرد & v \\
\hline 1 & & & & & & & & & & & & 1 & برنامه شمول اجتماعى و جذب جوانان & $\wedge$ \\
\hline 1. & 1 & 1 & 1 & & 1 & 1 & 1 & 1 & 1 & & 1 & 1 & مزاياى كارى مالى منصفانه براى زنان دستن و مردان & 9 \\
\hline
\end{tabular}




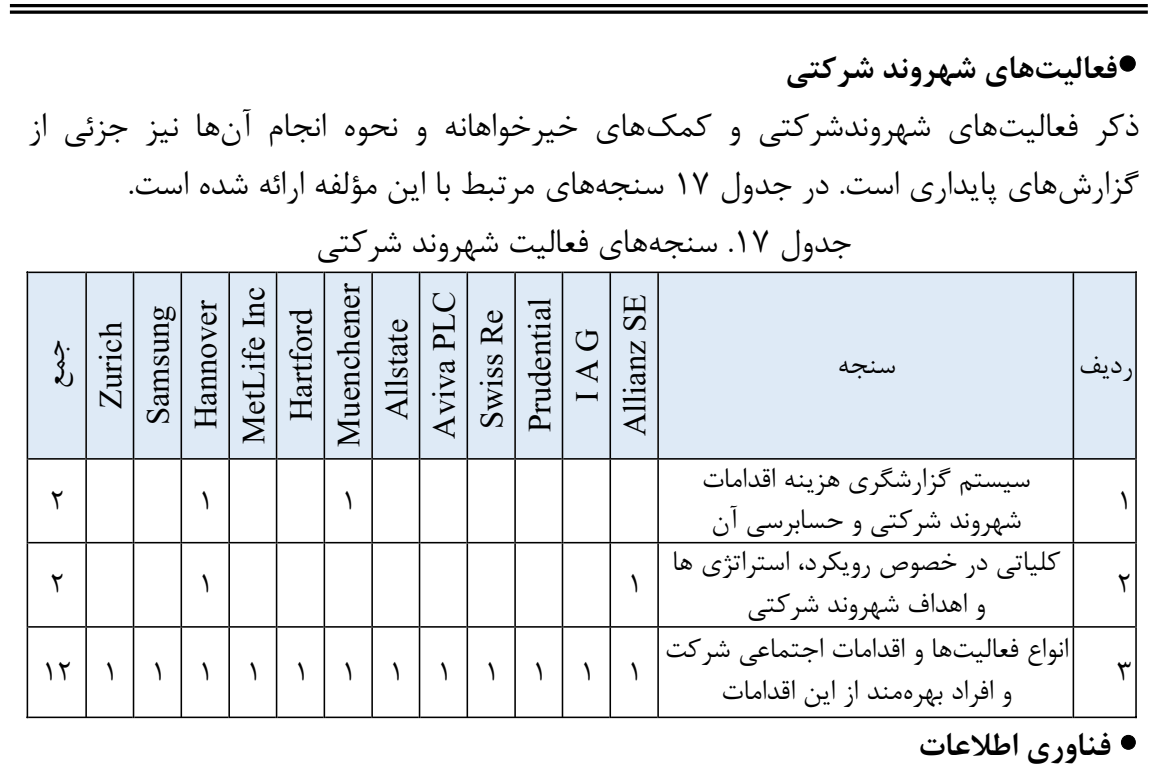

شركتها در تزارشهاى بايدارى خود مباحثى جون ديجيتالى سازى فعاليتهاى بيمه، حريم

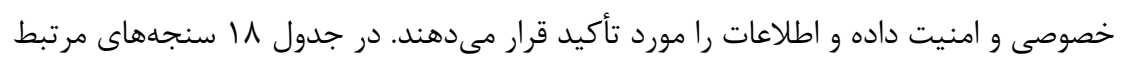
با مؤلفه فناورى اطلاعات ارائه شده است.

جدول 1/. سنجههاى فناورى اطلاعات

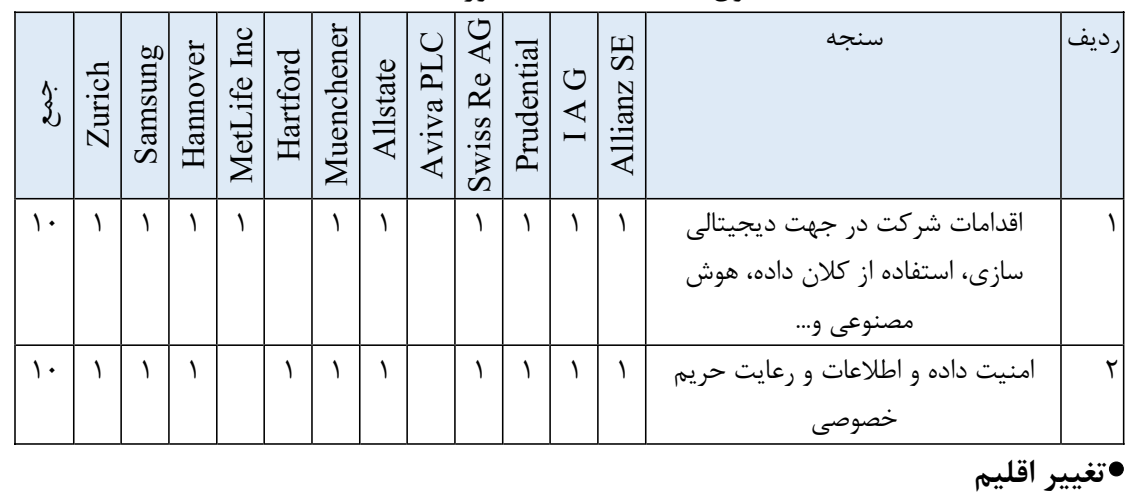

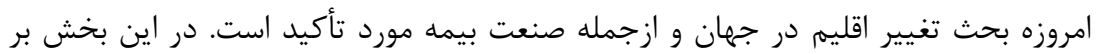

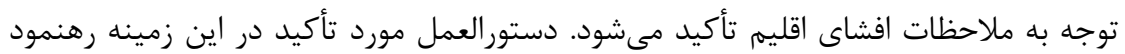

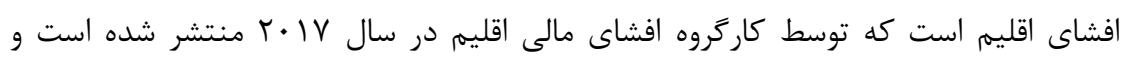
شركتها در متن اصلى كزارش هاى بايدارى خود به آن تأكيد مى تمايند. 


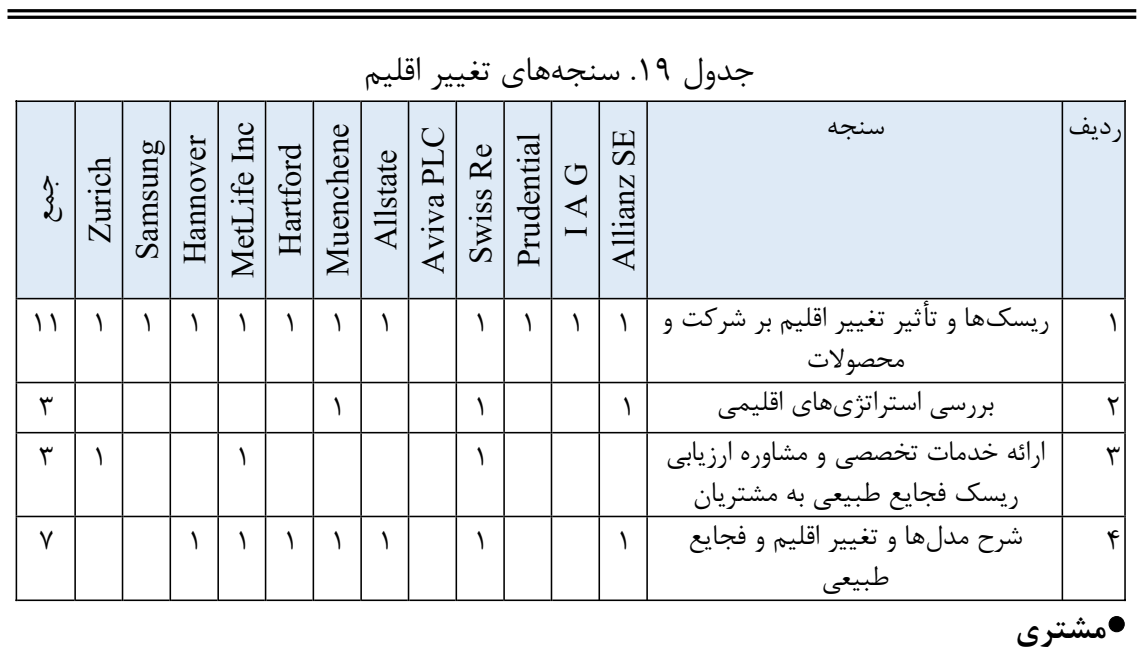

مشتريان و بيمه كذاران از ذينفعان كليدى صنعت بيمه هستند. توجه به نيازهاى مشتريان و

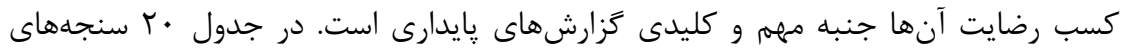
مرتبط با اين مؤلفه ارائه شده است.

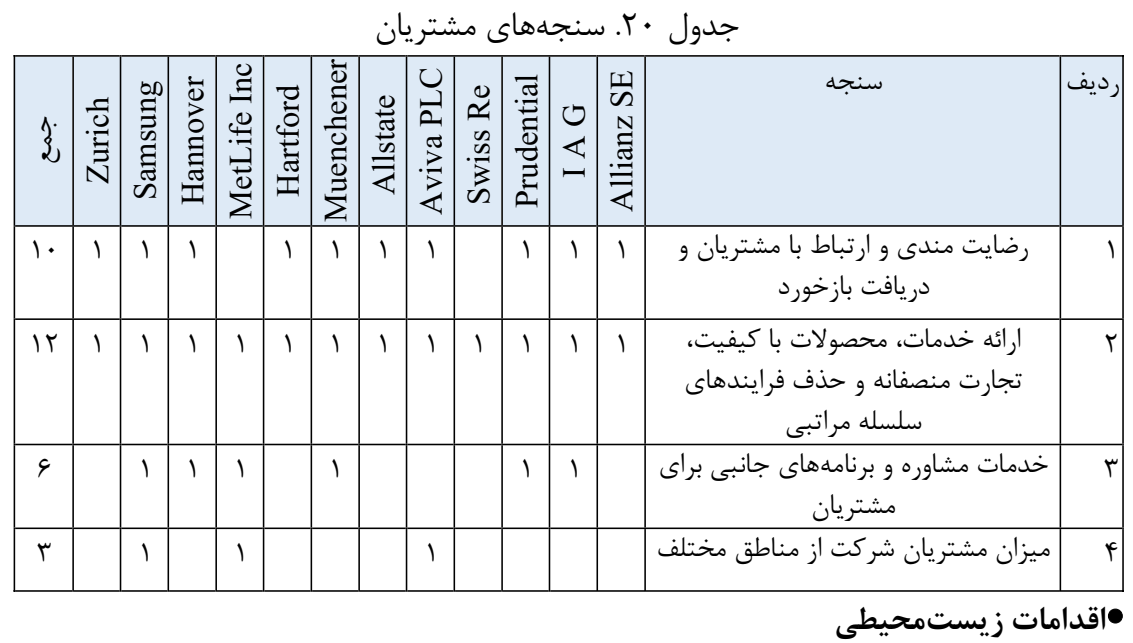

مسائل زيستمحيطى و استفاده از مواد و انرزى تجديد يذير، كاهش است استفاده از كاغذ و توليد

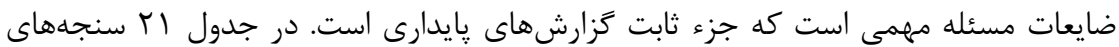

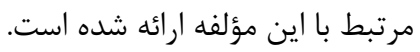




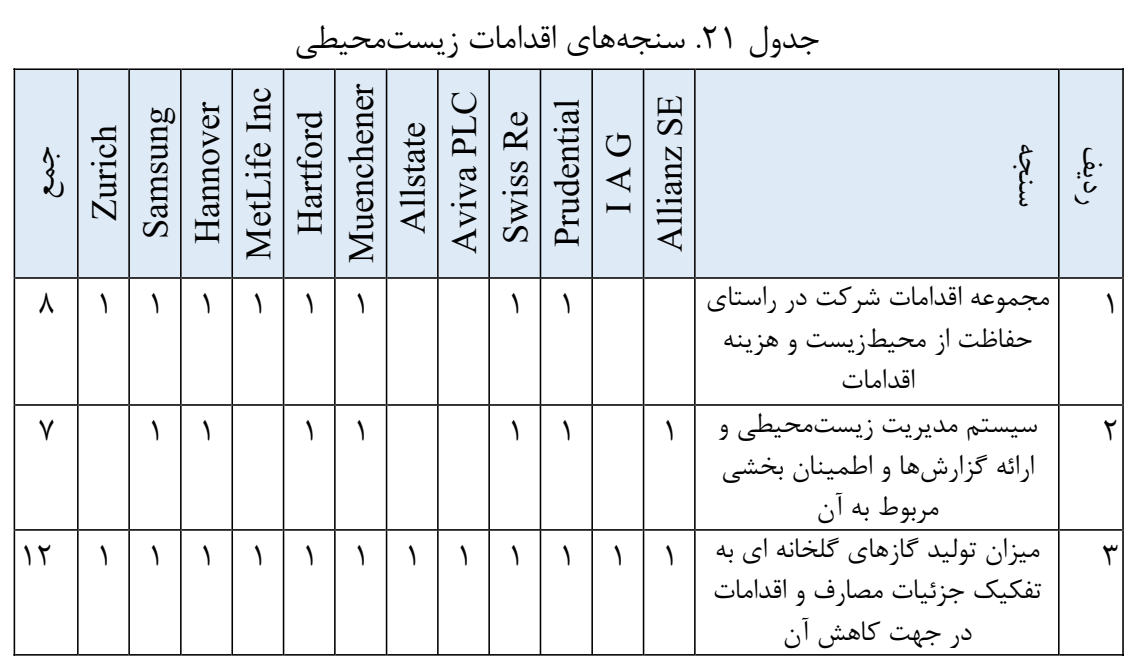

\section{9-نتيجه كيرى وبحث}

صنايع مختلف، داراى ابعاد و مشخصههاى زيستمدحيطى، اجتماعى و راهبرى مختلفى هستند.

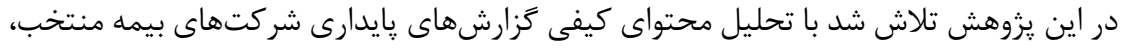

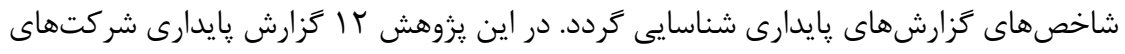

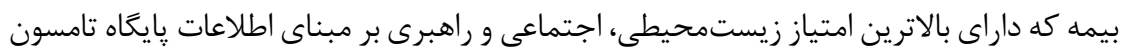

$$
\text { رويترز بودند، مورد تحليل قرار كرفت. }
$$

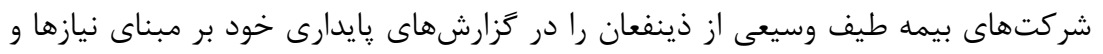

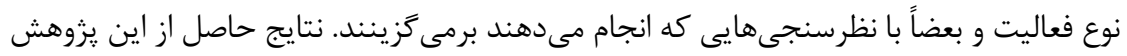

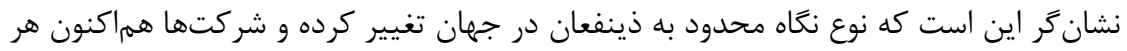

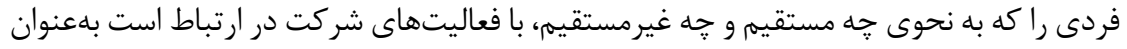

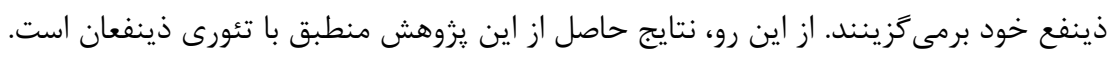

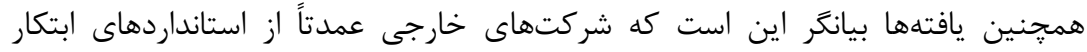

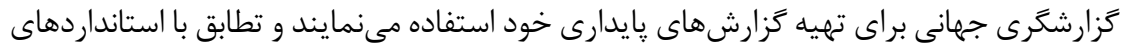

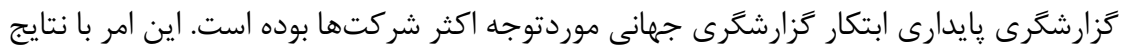

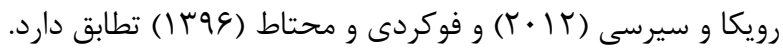

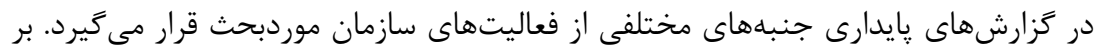

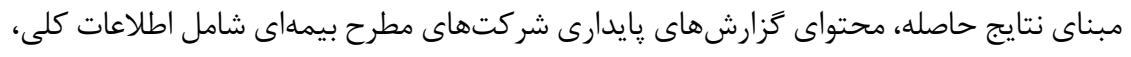


سرمايه كذارى بايدارى، بيمه پايدار، مباحث مربوط به فعاليت زيستمحيطى، مشتريان و كاركنان

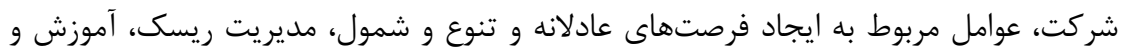

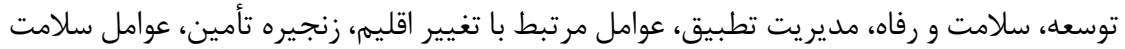

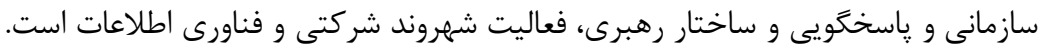

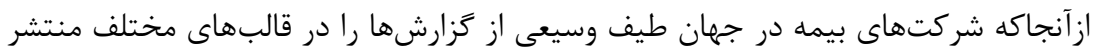

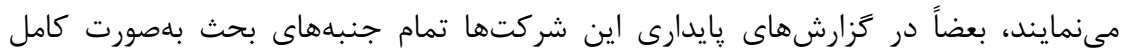

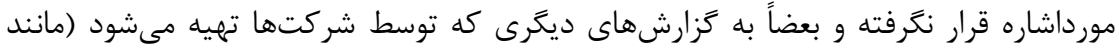

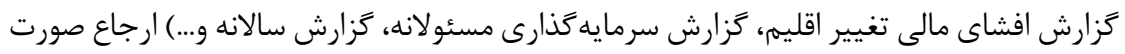

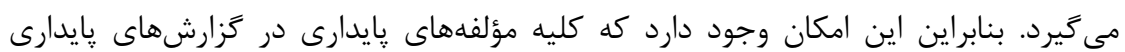

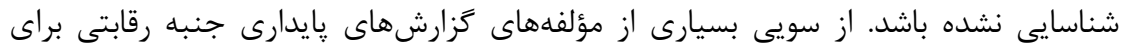

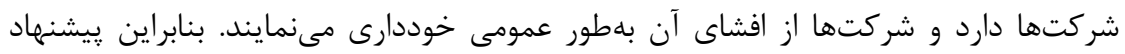

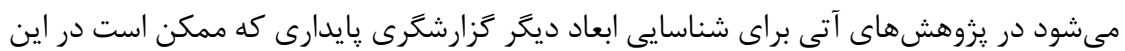

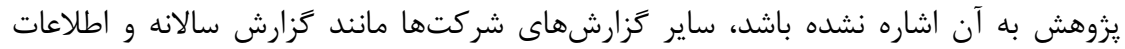

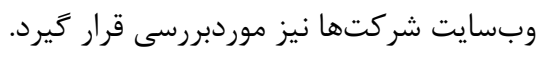

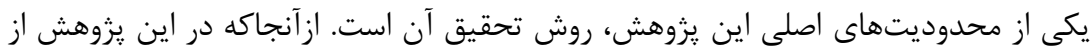

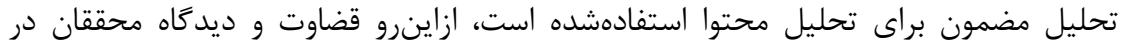

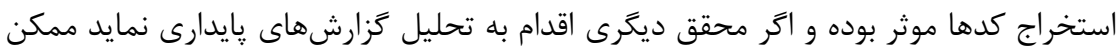
است تفاوتهايى در كدهاى استخر اجشده وجود داشته باشد با توجه به تحليل محتواى كيفى تزارشهاى

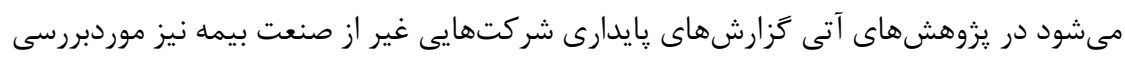

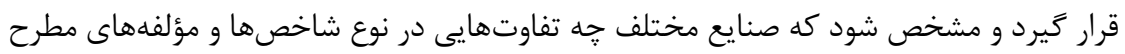

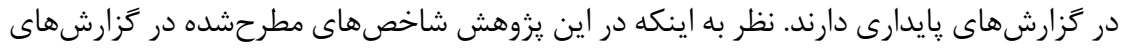

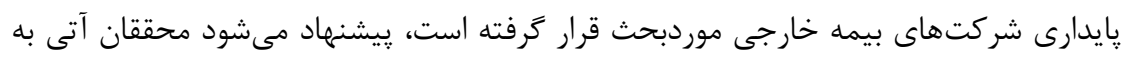

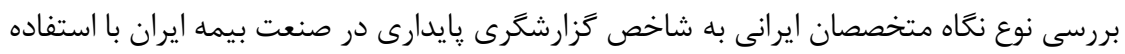

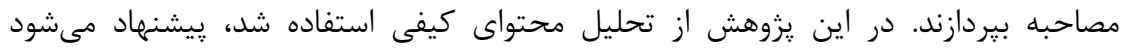

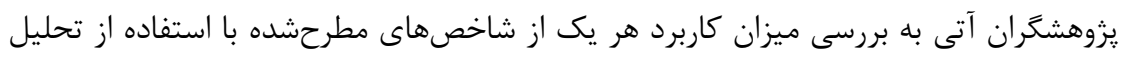

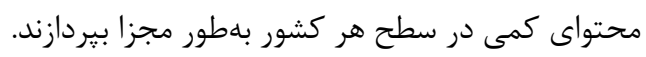

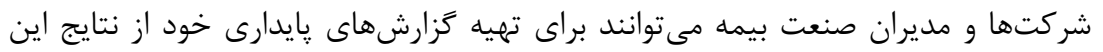

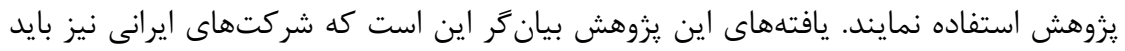

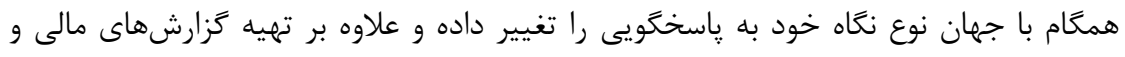


קاسخكويى به سهامداران و سرمايه گذاران به ساير ذينفعان خود ماند جامعه محلى نيز در قبال عملكرد خود ياسخكو باشند.

\section{V-تقدير و تشكر و ملاحظات اخلاقى}

اين مقاله مستخرج از رساله دكترى است و از حمايت مالى و معنوى يزوهشكده بيمه وابسته به

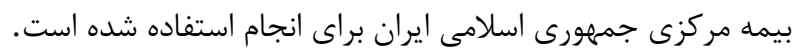

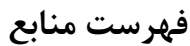

يورخانى ذاكله برى مظفر، جهانشاد آزيتا، حيدريور فرزانه. (99 (1)، ارائه الكَيى براى افشاء

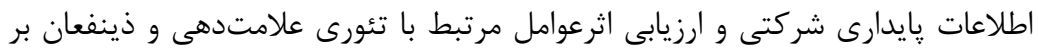

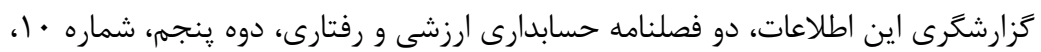

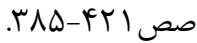

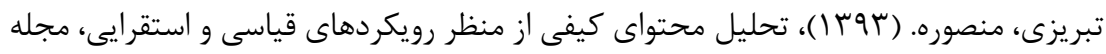

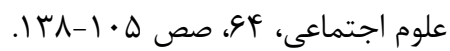

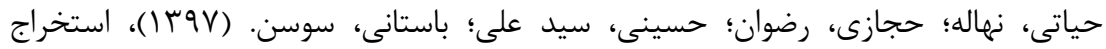

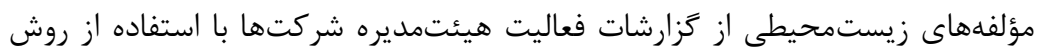

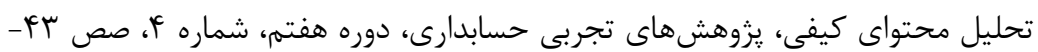
.$v \cdot$

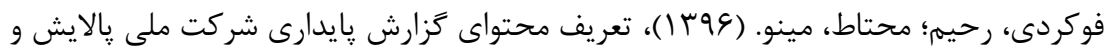

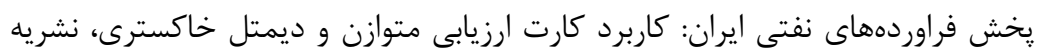

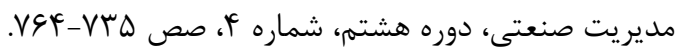

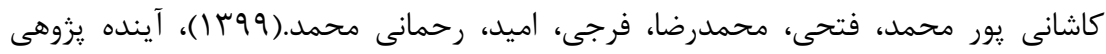

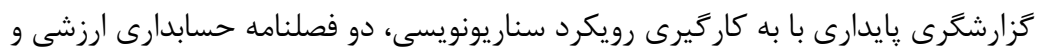

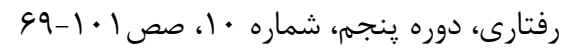

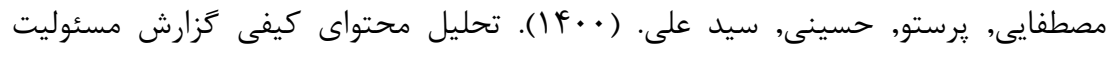

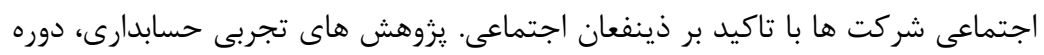

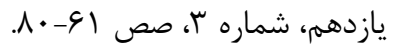

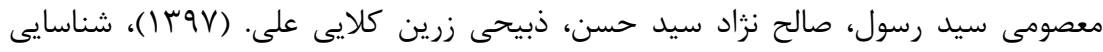

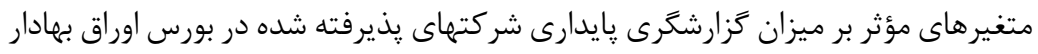

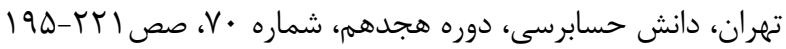




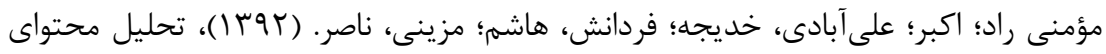

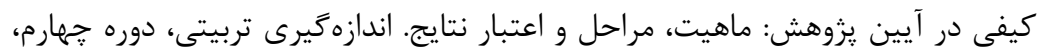

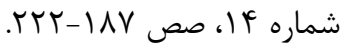

Allianz. 2019. Collaborating for a sustainable future. Sustainability report. https://www.allianz.com/en.html.

Allstate. 2019. How we serve society and our stakeholders. Sustainability report. https://www.allstate.com/

Aviva. 2019. Environmental, Social and Governance Data. Sustainability report. https://www.aviva.com/.

Braun, V., and V.Clark .2006. Using Thematic Analysis in Psychology. Qualitative Research in Psychology 3(2): 77-101.

Brockett,A., Z. Rezaee. 2012. Brief history of sustainability reporting. In Corporate Sustainability: Integrating Performance and Reporting. Wiley: Hoboken, NJ: 27-35.

Carnegie,G. Parker,L. and E.Tsahuridu. 2020.It's 2020: What is Accounting Today?. Australian Accounting Review, Wiley Online Library,last assessed 12 Agust 2021:65-73

Christofi,A.,P. Christofi,. And S. Sisaye. 2012. Corporate sustainability: historical development and reporting practices. Management Research Review 25(2): 157-172.

Eccles, R. G., and J. Stroehle. 2018. Exploring social origins in the construction of ESG measures. Available at SSRN 3212685..

Freeman, R.E.1984. Strategic Management: A stakeholder Approach. Boston, MA: Pitman.

Gray, R.H., D.L. Owen,. and K.T. Maunders. 1987. Corporate Social Reporting: Accounting \& Accountability.Prentice-Hall, Hemel Hempstead".

GRI. 2018. Sustainability Disclosure Database Data Legend. https://www.globalreporting.org/SiteCollectionDocuments/GRI-DataLegend-Sustainability-Disclosure-Database-Profiling.pdf

Griffin, J. J., and J. F. Mahon.1997. The corporate social performance and corporate financial performance debate: Twenty-five years of incomparable research. Business \& society 36(1): 5-31.

Hannover RE. 2019. Sustainability Report. https://www.hannover-re.com/.

Higgins, C., and B.Coffey. 2016. Improving how sustainability reports drive change: a critical discourse analysis. Journal of cleaner production 136:18-29.

Insurance Australia Group. 2019. Being guided by our purpose helps us create communities ready for anything. 2019 Sustainability report. https://www.iag.com.au/ 


\begin{tabular}{|c|c|}
\hline & دكتر رحمانى و همكاران، شناسايى مؤلفههاى تَزارشكَرى پايدارى در صنعت بيمه \\
\hline
\end{tabular}

Lock, I., and P.Seele. 2015. Analyzing sector-specific CSR reporting: Social and environmental disclosure to investors in the chemicals and banking and insurance industry. Corporate Social Responsibility and Environmental Management, 22(2):113-128.

Metlife. 2019. Sustainability Report. https://www.metlife.com/

Munich Re. 2019. Corporate responsibility report. 2019 Sustainability Report

Papoutsi, A., and M. S. Sodhi. 2020. Does disclosure in sustainability reports indicate actual sustainability performance?. Journal of Cleaner Production 260:121049.

Perez, F., and L. E. Sanchez. 2009. Assessing the evolution of sustainability reporting in the mining sector. Environmental management 43(6): 949961.

Prudential Financial, Inc. 2019. Sustainability Report. https://www.prudentialesg.com

Reuters, T. 2017.Thomson Reuters ESG Scores. https://www.refinitiv.com/en/sustainable-finance/esg-scores

Reuters, T. 2019. Environmental, social and governance (ESG) scores from Refinitiv. https://www.refinitiv.com/

Ribando J.M., and G.Bonne. 2010. A new quality factor: Finding alpha with ASSET4 ESG data. Thomson Reuter, Starmine Research Note,http://citeseerx.ist.psu.edu/viewdoc/download?doi=10.1.1.429.5 $77 \&$ rep $=$ rep $1 \&$ type $=$ pdf".

Roca, L. C., and C.Searcy. 2012. An analysis of indicators disclosed in corporate sustainability reports. Journal of Cleaner Production 20(1):103-118.

Şahin, Z., F.Çankaya,. and Z.Yılmaz. 2016. Content analysis of sustainability reports: a practice in turkey. In 7th European Business Research Conference : $15-16$.

Samsung Fire \& Marine Insurance. 2019. Good insurance company for better life. Sustainability Report. https://www.samsungfire.com/

SASB. 2019. Materiality map. Available online: https://www.sasb.org/

Scholtens, B. 2011. Corporate social responsibility in the international insurance industry. Sustainable Development 19(2):143-156.

Shea, M. I., and J. W.Hutchin. 2013. The insurance industry must champion sustainability. Thunderbird International Business Review 55(6): 659672.

Sikacz, H., and P. Wolczek. (2018). ESG Analysis of Companies Included in the Respect Index Based on Thomson Reuters EIKON Database. Research Papers of Wrocław University of Economics.

Sikacz, H., and P. Wolczek. 2018. ESG Analysis of Companies Included in the Respect Index Based on Thomson Reuters EIKON Database. Research Papers of Wrocław University of Economics. 
Swiss Re. 2019. Accelerating sustainable progress. Sustainability report. https://reports.swissre.com/

The Financial StabilityBoard (FSB). 2017. Task Force on Climate-related Financial Disclosures. https://www.fsb.org /

The Hartford. 2019. Inspired to reach higher. Sustainability Report. https://www.thehartford.com/

UN Principles for Responsible Investment. (n.d.a). Introducing responsible investment. Retrieved from http://www.unpri.org/introducingresponsible-investment.

UNEP Finance Initiative. 2012. Principles for sustainable insurance. Retrieved from www.unepfi.org/psi/the-principles/

Witkowska,J.2014.Stakeholders on the insurance market, olsztyn economic journal 9(3).

Zhou, Y. 2011, November. Materiality approach in sustainability reporting: applications, dilemmas, and challenges. In 1st World Sustainability Forum 1: 1-12.

Zurich Insurance Group.2019. Sustainability highlights. https://www.zurich.com/ 